7-1-2012

\title{
Law's Public/Private Structure
}

Christian Turner

University of Georgia School of Law, cmturner@uga.edu

DSPRN

\section{Repository Citation}

Christian Turner, Law's Public/Private Structure, 39 Fla. St. U. L. Rev. 1003 (2012),

Available at: https://digitalcommons.law.uga.edu/fac_artchop/1028

This Article is brought to you for free and open access by the Faculty Scholarship at Digital Commons @ University of Georgia School of Law. It has been accepted for inclusion in Scholarly Works by an authorized administrator of Digital Commons @ University of Georgia School of Law. Please share how you have benefited from this access For more information, please contact tstriepe@uga.edu. 


\title{
LAW'S PUBLIC/PRIVATE STRUCTURE
}

\author{
CHRISTIAN TURNER*
}

\begin{abstract}
Often derided for its incoherence or uselessness, the public/private distinction is rarely studied explicitly outside the state action doctrine in Constitutional Law. To ignore this distinction, however, is to miss the most fundamental sorting criterion in our law. Distinguishing whether public or private entities control (a) law creation and definition and (b) prosecution leads to a simple yet powerful taxonomy of legal systems. The taxonomy characterizes legal systems in terms of control over decisionmaking by our most basic institutional forms: the public and private. Thus, the proper categorization of laws within the system, for example whether a policy should be administered by Tort or by Contract, should depend on the relative institutional capacities of public and private actors. I propose a small set of basic, or "atomic," arguments concerning public and private capacities that can be used to generate such institutional comparisons.

The taxonomic model unifies formerly disparate areas of law and scholarship around simple arguments concerning the relative advantages of public and private institutions. This method has many implications, and the Article begins to explore several, including a comparison of private and public Constitutional Law, the placement of various kinds of laws in the model's schema, an application to the recent Supreme Court case of Robertson v. United States ex rel. Watson, and a unification of substantive classification and the property and liability rules of Calabresi's and Melamed's famous Cathedral.

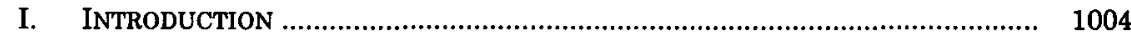

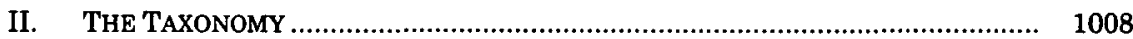

A. The Basic Legal Subjects ...................................................................... 1010

B. Meta-Law: Constitutional Law and Procedure ....................................... 1013

III. THE INSTITUTIONAL CALCULUS ................................................................ 1016

A. Uncovering the "Atomic Advantages" ................................................. 1018

B. Application to the Public and the Private............................................. 1021

1. Private Calculation Advantage ....................................................... 1021

2. Distributive Advantage ................................................................. 1022

3. Public Calculation Advantage ........................................................... 1023

4. Aggregation Advantage ................................................................... 1024

5. Resource Advantage ........................................................................ 1025

C. Compound Arguments .......................................................................... 1027

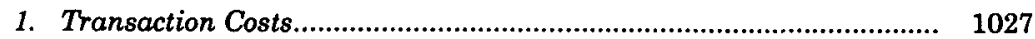

2. The Tragedy of the Commons.......................................................... 1028

3. Principal-Agent Problems .............................................................. 1031

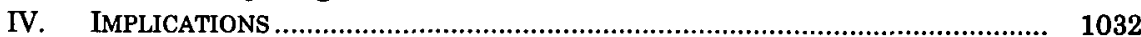

* Assistant Professor of Law, University of Georgia School of Law. J.D., Stanford University. Ph.D., Texas A\&M University. B.S., University of South Carolina. I wish to thank Daniel Bodansky and Joseph Miller for their extensive and helpful comments, the participants of the EACLE Annual Research Conference at Erasmus University Rotterdam, the participants of the Emory-UGA Faculty Workshop, the faculty workshops at the University of Arkansas Little Rock Law School and Mercer Law School, the participants of the Southeast Regional Junior Faculty Working Papers Conference, and, for help at a formative stage, the participants at the Public Nature of Private Property Workshop at Georgetown University Law Center. For their valuable feedback, I wish to thank Harlan Cohen, Christopher Elmendorf, Matthew Hall, Paul Heald, Gregory Klass, Lori Ringhand, Peter Rutledge, and Jeffrey Staton. For their research assistance, I am indebted to Patrick Baldwin, Sarah Craig, Wheat Kirbo, Andrew Pinson, Mark Silver, Jennifer Virostko, and Jeff Zachman. 
A. Trans-substantive Principles and Constitutional Law............................. 1033

1. The First Principle: Institutional Selection (Structure)....................... 1034

2. Privately Made Law ........................................................................ 1034

3. Publicly Made Laws................................................................... 1038

4. The Second Principle: Manifest Ill-Fit (Rights)................................. 1042

B. Tort and Crime: The Principles Applied to Procedure............................... 1045

1. Some Existing Approaches to the Tort/Crime Problem....................... 1046

2. Tort and Crime in the Model............................................................ 1049

(a) The Trans-substantive Principles in Procedure ......................... 1050

(b) Application of the Principles ...................................................... 1051

(c) Other Classifications as Derivative ........................................... 1057

(d) Historical-Substantive Misalignment ....................................... 1058

3. Robertson v. United States ex rel. Watson ........................................ 1060

C. Iluminating Law's Darker Corners .................................................... 1064

D. A Possible Third Dimension: An Aspect of an Aspect of the Cathedral..... 1067

V. CoNCLUSION..................................................................................... 1072

\section{INTRODUCTION}

All legal systems possess a common, elementary structure. Although law's contents and methods obviously differ wildly among societies, it is nonetheless possible and useful to view legal systems as highly individuated descendants of a bare and neutral template. Identifying the right sort of descriptive template reveals deep connections among and within legal systems, connections that reframe many of law's larger questions: Why do we have contract, tort, and criminal law? Are these subjects merely idiosyncratic developments within particular legal systems or are they universal legal categories? Is the constitutional law governing tort and criminal law similar to the law that governs contract interpretation and enforcement? Is there a way to reduce complex, subject-specific legal issues to more basic and trans-substantive normative questions?

In this Article, I describe a theory of legal systems that provides answers to these and other questions. The taxonomy at the heart of the theory derives its analytical power from a single idea: that the most fundamental legal questions concern the choice between public and private decisionmaking.

This may seem surprising. Many have assumed that the public/private distinction is long dead. Slain by Duncan Kennedy in $1982,{ }^{1}$ it is now seldom observed outside the strained, ends-driven

1. Duncan Kennedy, The Stages of the Decline of the Public/Private Distinction, 130 U. PA. L. REV. 1349 (1982). Kennedy used the public/private distinction as a paradigmatic example of an apparently sharp legal distinction that is destined to collapse via a predictable process: (1) the emergence of "hard cases with large stakes," (2) legal recognition of intermediate categories, (3) the recognition that every case is an intermediate one in some respect, (4) an attempt to salvage the distinction by arguing that it is in fact a spectrum between idealized poles, (5) the development of canned, opposing 
reasoning found here and there among the pages of the U.S. Reports. What appears to be "private" can always be characterized as "public."2 Private contracts, after all, are public to the extent they are enforced by courts. Conversely, the public acts through private individuals who occupy positions in the government. The arguments for labeling an activity or institution "public" or "private" are as predictable as the difference between them is indeterminate. It is therefore not surprising that relatively little scholarship has attempted an interdisciplinary analysis of the role the public/private distinction plays in our law.

To ignore the distinction, however, is to miss the most basic sorting criterion in our legal system. Indeed, separating public from private is an inevitable task in any legal system. To form a government is to agree first and foremost on those decisions a collective will make together and those it will leave for its constituents. Appreciating the differences between public and private control of lawmaking and administration is the key to answering the questions posed above.

To achieve this and to overcome the specter of indeterminacy, we must first recognize that most of our legal interactions and institutions have both public and private aspects. Often, the reason the distinction appears muddied or mixed is that a single dispute involves public and private control over different questions.

For example, Morton Horwitz cites Fuller and Perdue's work on contract damages to argue that contract is not entirely "private," since contract damages are state-imposed sanctions that are calibrated to achieve policy ends. ${ }^{3}$ This argument is correct as far as it goes. Most contract disputes are not solely governed by "private law." While their adjudication is initiated by a private individual and is governed by privately created law, they often, though not invariably, ${ }^{4}$ result in publicly determined remedies: court-ordered damages. These questions appear mixed in nature because they are not resolved entirely by the public or entirely by private individuals, but in fact the public/private distinction critically informs each dimension of the conflict separately. By focusing narrowly on the

arguments, which can be made in every case, concerning an issue's placement on the spectrum, and finally (6) what Kennedy calls "loopification," wherein the poles of the spectrum are drawn closely together. See id. at 1350-57.

2. See, e.g., Shelley v. Kraemer, 334 U.S. 1, 19-20 (1948) (holding that the enforcement of private covenants by public courts is "state action"); Marsh v. Alabama, 326 U.S. 501, 505-07 (1946) (finding a private, company town was a state actor because it exercised "public function[s]").

3. Morton J. Horwitz, The History of the Public/Private Distinction, 130 U. PA. L. REv. 1423, 1426 (1982).

4. See infra notes 184-89 and accompanying text. 
difference between public and private control over discrete legal decisions, much of the difficulty of indeterminacy is avoided.

I exploit this basic and more focused distinction between public and private decisionmaking to construct a simple taxonomy that provides important insight into the structure of legal systems. This is not a "theory of everything." Quite plainly, one cannot hope to characterize all legal systems in minute detail by asking only a few questions. But it is possible to see that many seemingly disparate legal issues are differently costumed aspects of the public/private dichotomy, nonetheless governed by fundamentally the same arguments.

The questions I pose to sort the laws of a legal system are: Is the law publicly or privately made? Is its adjudication publicly or privately initiated? ${ }^{5}$ From the binary sequence of answers that results from the first two questions, we will obtain a taxonomy of laws that corresponds roughly with the traditional categories of tort, contract, and criminal law.

The central purpose of this approach is to show that legal systems can be ordered by discrete choices between public and private decisionmaking, thus reframing many legal issues as questions of basic, institutional choice: that between public and private actors. While the literature abounds with analyses of the institutional dynamics of, say, legislatures and courts, ${ }^{6}$ the much more elemental divide between public and private entities has yet to be fully and systematically explored. Doing so will permit us to understand more precisely, across the legal landscape, what our legal disagreements actually concern by reducing complex arguments to questions of institutional competency.

With the descriptive taxonomy in hand, we can predict how a society will, and argue normatively how it should, structure its laws based on the application of interdisciplinary, "atomic" arguments concerning only the differing capacities of public agents and private individuals. I call them "atomic," because they are the basic elements from which compound arguments concerning legal regulation are constructed. Much of what at first appears to be subject-specific argumentation over questions such as whether to permit certain

5. These are rough versions of the taxonomic criteria. They will be made more precise infra. In addition to these, I also explore a third question: Are the consequences of its violation publicly or privately determined? I will argue that this yields the distinction between property rules and liability rules, thus unifying important aspects of Calabresi and Melamed's "Cathedral." See generally Guido Calabresi \& A. Douglas Melamed, Property Rules, Liability Rules, and Inalienability: One View of the Cathedral, 85 HARV. L. REV. 1089, 1090 (1972).

6. See, e.g., Int'l News Serv. v. Associated Press, 248 U.S. 215, 262-67 (1918) (Brandeis, J., dissenting). 
kinds of contracts and whether to recognize various torts is only a composition of a small number of trans-substantive, atomic arguments.

Stated roughly, these atoms are arguments that either public institutions or private entities: (1) are good at estimating the decision's impact on others (which of them has a "private calculation advantage"), (2) are unselfish within the context of the decision (which has a "distributive advantage"), (3) are able to evaluate the decision according to public norms (which has a "public calculation advantage"), and (4) are able to effect the decision (which has a "resource advantage"). ${ }^{7}$ Armed with a model that defines legal systems in terms of public and private control and a set of elemental arguments to evaluate public and private competencies, it is possible to predict and critique the structure of a given legal system.

I begin, in the next Part, by describing the fundamental public/private distinctions, those between public and private law creation and public and private prosecution (or law enforcement). These distinctions together result in a two-dimensional model of legal systems, populated with the familiar categories of Contract, Tort, and Criminal Law, along with an unfamiliar and interesting category I call Parens Patriae. ${ }^{8}$

In Part III, I define the atomic arguments that can be made in favor of public or private decisionmaking. Again, they are "atomic" because they compose the seemingly more complicated and specific arguments that define, classify, and limit laws within a legal system.

In Part IV, I use the atomic public/private arguments to derive trans-substantive, secondary rules that can be used to categorize law appropriately within the model and to constrain the actors that make law and prosecute violations. The doctrinal importance of understanding these boundaries was brought to the fore in a recent United States Supreme Court case, Robertson v. United States ex. rel. Watson, that raised the question whether criminal contempt could be prosecuted by a private party. ${ }^{9}$

In conclusion, I indicate further applications of the model, from pedagogy to property to pluralism. The applications are far-reaching, as the model reveals that much of law's apparently complex structure results from the same, simple form repeated in overlapping ways,

7. See infra Part III.A.

8. I will emphasize again, infra Part II.A, that these labels are suggestive only. They are not perfectly isomorphic with any Restatement's definition of the body of, say, tort law or contract law. But being suggestive, and thus motivating intuition, at the risk of some confusion is worth the costs. In an effort to avoid ambiguity, I will capitalize the categories in the taxonomy and leave uncapitalized the tort law, contract law, criminal, and even constitutional law of the Restatements and casebooks.

9. 130 S. Ct. 2184,2185 (2010). 
and at different scales. While the content of individual laws cannot always be understood this way, law's broad contours inevitably must be. To put it differently, not all laws are made of the atoms that are the discrete ways of dividing public from private. But law's skeleton is.

\section{The TAXONOMY}

The public/private distinction is among what Norberto Bobbio has elegantly described as one of our species' " 'great dichotomies,' " and it is therefore no surprise that it provides a lens into the fundamental structure of legal culture. ${ }^{10}$ Such dichotomies, Bobbio tells us, (a) divide the world into two mutually exclusive categories and (b) subsume other important distinctions. ${ }^{11}$ The aim of this Article is to show how the public/private distinction subsumes a host of seemingly unrelated legal questions. Much of law's structure and many of its specific questions turn out to be secondary to this Great Dichotomy applied to two basic legal questions.

The initial goal, in this Part, is purely descriptive. The taxonomy is, on one level, a formal classification. ${ }^{12}$ It is inarguably $a$ way to categorize legal systems. That it is, both conceptually and normatively, a useful way to do so will be demonstrated in the Parts that follow.

I claim a bit more, however. Every legal system in fact grapples with the public/private questions I ask here. This is so because every collective must decide with respect to the basic questions that innervate the two-dimensional construct I describe (loosely: law creation and prosecution) whether to act individually or together. The taxonomy therefore provides a description of the actual decisions facing any collective and every legal system. ${ }^{13}$ Even if individuals do

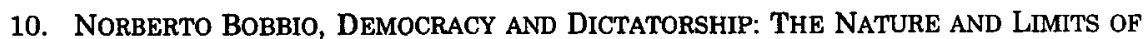
STATE POWER 1 (Peter Kennealy trans., 1989).

11. Id. at $1-2$

12. Emily Sherwin has helpfully described a number of ways that classification in legal theory proceeds. Emily Sherwin, Legal Taxonomy, 15 LEGAL THEORY 25, 28 (2009). In her taxonomy of taxonomies, my approach would be called a "formal classification." See id. at 33-34. This is so because my "predominant concern is with the internal logical relationship among legal categories rather than the social functions of or higher-order reasons for the legal rules grouped within them." Id at 33. As Sherwin points out, such classifications, so long as logically sound, cannot claim to be correct or incorrect. See id. at 33-34. As such, it is either useful or not, but it is a category error to ask whether it is right.

13. I use the term "collective" here to make clear that the theory also applies to entities other than what we formally recognize as "states." A private organization is a collective, and it has a legal system, however informal, that governs whatever coercion it can apply. Though the collective is "private" when viewed from the perspective of the state in which it is embedded, it is "public" when viewed as a self-contained legal system, even if subject to the constraints imposed by a hierarchically superior public, like the state. See, e.g., infra note 64 (discussing how private entities within a legal system may form their 
not consciously think of the public/private distinction when constructing the legal system that will govern them, they nonetheless make choices concerning it that are of fundamental importance. ${ }^{14}$

After all, law is a collective's self-conscious scheme to govern the imposition of whatever coercion the collective is able to muster. Basic to the application of coercion is the question of what conditions will trigger its application. In other words, the collective must ask under what circumstances it will even consider coercion (the enforcement, or initiation, question) and how it will decide whether to coerce once it does consider it (the law creation question). And basic to these questions is the choice between granting to the collective itself or to individuals the power to answer them. ${ }^{15}$

A surprising degree of understanding concerning optimal classification and even content of law can be gained by combining this taxonomic model, the atomic public/private arguments I describe in the next Part, and some information concerning the norms of the collective. It is this additional, collective-specific information that is critical to reaching normative conclusions. I explore some examples in Part IV.

But without knowledge of the collective's wants, the taxonomy provides no normative critique of the collective's legal system, only a method of classifying its law according to the basic choices it has made. ${ }^{16}$ Once defined, the taxonomy categorizes relentlessly and

own "public," perhaps inferior to the one in which it is embedded, and citing sources that describe non-governmental collectives and private ordering).

14. Some support for the ontological nature of the model derives from its neat alignment with the major distinctions found across many modern and ancient legal systems. Nearly all legal systems that in fact have both public and private law recognize that division as basic, by labeling it as such, teaching it as such, establishing different courts for public and private law, and establishing different doctrinal approaches that operate uniformly within each area. If a model is highly descriptive of the de facto practices of divergent legal systems, then there is some evidence that the model describes an inherent distinction within all legal systems.

15. One might say that fundamentally we specify the conditions of coercion, and prior to that is the question of who specifies the conditions. The public/private distinction is more fundamental than, meaning prior to, the "who" question. If the collective allows, under some circumstances, any member to specify these conditions, we say that it has deferred to private power. If, by contrast, the collective specifies some more particular locus for the decision, the decision is public, even if the decisionmaker is not expected to act according to public norms. The point is that in the latter case the public controls the identity of the decisionmaker. Subsequent to this determination, that it will select the decisionmaker, the public moves to the subsidiary question of how such decisionmaker is determined. This sort of "who" question is one of substantive Constitutional Law, as we shall see in Part II.B infra.

16. As Sherwin puts it:

A formal scheme of legal classification is normatively inert. By their nature, the rules being classified are normative: a rule of law implies institutional consequences, such as a legal right to damages. Yet the 
without judgment, providing a descriptive lens on legal systems ranging in kind from our own to the suffocating dictatorship of the autocrat Rex. ${ }^{17}$ It is initially with this purely descriptive goal in mind that I construct and explain a taxonomic, institutional model of legal systems.

\section{A. The Basic Legal Subjects}

I will focus first on two distinctions among laws that together create four legal categories. Three of these categories are roughly equivalent to the major substantive areas of our own legal system: Contract, Tort, and Criminal Law. The fourth category is a bit of an outlier in our legal culture, but not exactly an empty set.

The first distinction is between those legal norms that are created publicly and those created privately. In short, the focus is on the source of those rules that govern primary behavior. Thus, we will ask whether the criteria for bringing to bear the coercive power of the state are privately set or publicly set. A private contract is an example of the former. A legislatively imposed highway speed limit is an example of the latter. In contract, the parties themselves specify the legal obligations they will undertake. They are the lawmakers. The speed limit is set by the legislature, a public body.

Two caveats will help to sharpen the meaning of this distinction. First, the original author of the text forming the basis of the legal duty is immaterial. Within the category of publicly created law, the public may incorporate standards from the private marketplace. For example, medical malpractice torts are based on the standard of care prevailing among private physicians. But under my taxonomy, such torts are still publicly formulated. The question is not whether the content of laws originates from official, deliberative bodies or from private individuals. Rather, the question is whether the public or private individuals control the law's content. The public chooses to define the medical malpractice tort based on prevailing market standards. But no private individuals control that standard or could

classificatory scheme itself, the structural rules that shape it, and the categories it yields have nothing to say about how courts should decide cases.

Sherwin, supra note 12 , at 34 . Rather, the classification provides glue that connects collective-specific normative commitments with deduced structural choices that may have been less obvious without the model. See id. at 33-34.

17. Here I refer to H.L.A. Hart's caricature in THE CONCEPT OF LAW 52 (2d ed. 1994). Rex is a selfish tyrant who makes law for his people only to satisfy his own ends. See id. His system occupies a polar extreme on the fully participatory/fully enslaved political spectrum. See id. at 52-53. I will refer to him throughout, as a reminder of the normative diversity of legal systems. 
stand in the way of its amendment. The public is the author of this law. It has chosen how to govern instances of medical injuries. So too, a private contract, clearly representing the choices of the parties to the contract, can incorporate the language of others or even the language of public laws. Doing so does not mean that others or the public has made this law between the parties, only that the parties have borrowed such law for their purposes. They still control.

Second, the model is only concerned with those obligations a collective coercively enforces. Thus, private lawmaking does not include unenforceable private agreements or privately policed norms. Lawmaking authority that is left to private individuals must be distinguished from those areas of our lives over which a collective decides not to exercise its coercive powers at all. ${ }^{18}$ The latter are not a part of this model of legal systems. ${ }^{19}$

The second distinction used to generate the taxonomy concerns whether enforcement may be initiated privately or publicly. Who makes the "decision to decide" whether the collective will coerce? May an individual require the group to apply its rules, whatever they are, to decide whether to compel another to pay some kind of compensation? Or does the group itself determine whether it will render a decision ordering one to do what he or she wishes not to do?

In other words: who can "call the question"-private parties or only the public? I will often, risking some ambiguity for the sake of brevity, refer to the resolution of this question as being in favor of either public or private "enforcement." By enforcement, though, I mean only the action described above, forcing the collective to determine whether to coerce, not subsequent attempts to collect judgments or otherwise to ensure that decisions already made are carried out and not even the act of prosecution itself. The question is, again, based on power. Who can force adjudication?

There are several other ways one might attempt to divide law based on various kinds of public or private control over, say, a

18. As Tay and Kamenka put it:

[T] here is an obvious sense in which all law is social and public, preceding any given individual and confronting him as something outside himself, backed by the state or the community. The classification of law into public and private is a classification within this general feature of law, distinguishing some bodies of law from others within a single system.

Alice Erh-Soon Tay \& Eugene Kamenka, Public Law - Private Law, in PUBLIC AND PRIVATE IN Social LIFE 67, 82 (S.I. Benn and G.F. Gaus eds., 1983).

19. Of course, the group's decisions concerning to what extent and under what conditions it will back private decisions with group-level coercion is highly political, meaning that they have enormous implications for and are reflective of the distributive policies of the group. 
lawsuit. Is the litigant represented publicly or privately? Does the remedy inure to public or private benefit? Though I briefly take up this latter question again, ${ }^{20} \mathrm{I}$ find more fundamental the question posed here. What is asked is whether a private person or the public has the power to force a collective determination, a power that necessarily imposes the cost of deciding on the group as a whole. ${ }^{21}$ This is a fundamental question because many of the distinctions between tort and criminal law are, at bottom, only the natural consequences of standard distinctions between public and private capacities when applied to the power to "call the question."

These two distinctions-who creates duties and who enforces duties-are basic in the following sense. Any collective will have to decide when it will coerce its members. When conflicts arise between a collective's members, "the fundamental thing that law does is to decide which of the conflicting parties will be entitled to prevail." ${ }^{22}$ To do this, it must decide what law to apply, whether to defer to the desires of private individuals or to impose the will of the collective itself. It must also determine who gets to decide whether such conflicts should be eligible for coercive determination in the first place.

As the table below summarizes, I will affix familiar labels to the categories created by the answers to these two questions. The area of privately enforced, privately created duties will be called Contract Law. The area of privately enforced, publicly created duties will be called Tort Law. And the area of publicly created, publicly enforced duties will be called Criminal Law. The final area, privately created but publicly enforced duties, is an obscure one in American law but not without content, and I will call it Parens Patriae. ${ }^{23}$

\begin{tabular}{|c|c|c|}
\cline { 2 - 3 } \multicolumn{1}{c|}{} & Privately Created & Publicly Created \\
\hline $\begin{array}{c}\text { Privately } \\
\text { Enforced }\end{array}$ & Contract & Tort \\
\hline $\begin{array}{c}\text { Publicly } \\
\text { Enforced }\end{array}$ & Parens Patriae & Criminal Law \\
\hline
\end{tabular}

20. See infra Part IV.D.

21. Even if an individual does have such power with respect to a conflict, the public may also have the power to pursue resolution. This might be necessary, as will be further elaborated below, if the public net benefit of resolution is greater than the private net benefit to any individual empowered to demand resolution.

22. Calabresi \& Melamed, supra note 5, at 1090.

23. What about Property? Perhaps to the chagrin of we who teach and love the subject, the model demonstrates what we have long known: Property is not a fundamental legal subject of the same sort as Tort, Criminal Law, and Contract. See infra Part V. 
Though I suggestively label these categories with the major headings of our substantive law, I do not mean to argue, for example, that privately created, privately enforced law is our contract law. Rather, I am calling "Contract" all such laws. The contract law of the states tends to fall entirely within this category. But so too does some other law, such as gifts, easements, and real covenants, which might not be considered "contract law" by some. "Tort," in this Article, means all publicly created, privately enforced laws, not the set of law that a jurisdiction itself labels "tort law." Thus, statutes that provide private rights of action are "Tort" laws under my taxonomy, even though some might consider at least some such laws something other than "tort law."

On the one hand, these headings are only labels. I am not directly entering the debate over questions such as: "What is (our) tort law?" Rather, the effort here is to observe that law is fundamentally different depending on whether various aspects of it come under public or private control. The resulting categories need labels, and I have given them highly suggestive ones. Unfortunately, maintaining the appropriate suggestion of what these categories are comes at the cost of potentially confusing them with the bodies of law described in Restatements bearing their names.

On the other hand, the fact that our tort law, our contract law, and our criminal law generally do fit within these categories is no accident. It is demonstrative of the fact that all societies must wrestle with how to divide control over law between the public and its members. Given the inherent capacities and limitations of public institutions and private citizens, it should not be surprising that many societies resolve these divisions similarly.

\section{B. Meta-Law: Constitutional Law and Procedure}

Every public has some means for creating and recognizing the duties that will be analyzed in a case and some means for orderly processing decisions whether to coerce. I call these two sets of methods Constitutional Law and Procedure, respectively.

\begin{tabular}{|l|c|c|c|}
\cline { 3 - 4 } \multicolumn{1}{c|}{} & \multicolumn{2}{c|}{ Constitutional Law } \\
\cline { 3 - 4 } \multicolumn{1}{c|}{ Procedure } & Privately Created & Publicly Created \\
\cline { 2 - 4 } & $\begin{array}{c}\text { Privately } \\
\text { Enforced }\end{array}$ & Contract & Tort \\
\cline { 2 - 4 } & $\begin{array}{c}\text { Publicly } \\
\text { Enforced }\end{array}$ & Parens Patriae & Criminal Law \\
\hline
\end{tabular}


This additional structure might seem at first to be driven by a desire to add in the bits of law not obviously covered by the four categories so far derived. In fact, the public/private perspective of legal systems turns out to be a helpful way to understand the array of secondary rules, power-conferring fragments of law, "legal rights," and other meta-law. What I call Constitutional Law is the entire set of secondary rules that governs the making of laws, and by Procedure, I mean the set of secondary rules that governs the adjudication of alleged breaches of the laws.

In this fashion, I propose a unified way of thinking about the meta-rules of privately created and publicly created law. To take up but one implication of this understanding, I will focus on the metalaw of Contract. While the course of study in law school commonly called "torts" is primarily about the substantive rules of that area, the subject commonly called "contracts" is mostly, and often entirely, a study of what I call the Constitutional Law of Contract. ${ }^{24}$

If we think of Constitutional Law, generally, as describing the structure of a collective's decisionmaking entities, including contracting private parties, and the extent of the powers of those entities (i.e., their rulemaking authority and obligations to respect rights), then it should be obvious that the body of law we call "contracts" is really a field of Constitutional Law. Indeed, the study of "contract law" could hardly be other than a study of structure and rights. The substantive legal duties created by contract law are elaborated in countless contracts and are not easily amenable to systematic study. Moreover, "substantive contract law," the obligations actually established through particular contracts, is generally far less instructive, even for the transactional lawyer, than a combination of (a) the law governing recognition of privately created law, i.e. the Constitutional Law of Contracts, and (b) the particular substance of typical contracts in the lawyer's field of concentration.

So, returning to the constitutional questions of Contract Law, how do private members of a collective create enforceable duties? How do they "pass laws"? In our system, individuals may do so through mutual assent manifested in a particular manner of offer and

24. As with the substantive labels (Contract, Tort, Criminal Law, and Parens Patriae), I use the phrases Constitutional Law and Constitutional Law of Contract in a specialized manner. As will be made clear below, I do not mean by the Constitutional Law of Contract, our existing constitutional doctrines constraining governmental impairment of contracts or otherwise relating to public regulation of contracts. I mean the metalaw governing the structure and rights pertaining to private lawmaking. Who can make a contract? How can they do so? What kinds of contracts are they permitted to make? Can a contract be struck down for regulating in forbidden areas? These are the questions resolved by the Constitutional Law of Contract, just as their public analogues are answered by Constitutional Law. 
acceptance. But there is more structure in our own Constitutional Law of Contract than is contained in even the elaboration of what counts as an offer and what counts as an acceptance. There are rough standards, sometimes vague and sometimes not, concerning the identities of the rule promulgators: age requirements, restrictions on dealing with those of less than sound minds, and more. There are rules concerning the procedures for "passage": the statute of frauds, the mailbox rules, meeting of the minds, and consideration. ${ }^{25}$ There are rules concerning interpretation in the face of ambiguity and silence, resulting in presumptions and default rules-just as there are for public statutes. ${ }^{26}$ There are constraints on substance: the rule that contracts do not impose obligations on nonparties, ${ }^{27}$ the rule against illegal contracts, the rule against unreasonable restraints on alienation, and the rule, in general, against agreements that violate public policy. ${ }^{28}$ All of these serve the same functional purpose as the analogous public constitutional rules concerning structure and lawmaking.

Just as on the public side, private laws are constrained by rights. It should come as no surprise that every "right" can also be viewed as a kind of structural limitation. Scholars of the constitutional law of Crime and Tort have long identified and debated this parity. ${ }^{29} \mathrm{We}$ might, however, identify rights in Contract Law as established chiefly by the unconscionability doctrine, which interestingly tracks the procedural and substantive due process doctrines of our constitutional law, ${ }^{30}$ the very doctrines that that have been read to be

25. See Joseph M. Perillo, The Origins of the Objective Theory of Contract Formation and Interpretation, 69 FORDHAM L. REV. 427, 427 (2000) (discussing how these doctrines serve the "objective theory" to determine whether a contract exists or not).

26. See Cass R. Sunstein \& Edna Ullmann-Margalit, Second-Order Decisions, 110 Ethics 5 (1999), available at http://ssrn.com/abstract=19384 (observing the similarity between presumptions in both contract law and statutory interpretation designed to fill in what the lawmakers would have intended or to incentivize lawmakers to be clear and disclose intentions).

27. Covenants and easements that run with the land are important exceptions in Anglo-American law. See, e.g., Jeffrey E. Stake, Toward an Economic Understanding of Touch and Concern, 1988 DUKE L.J. 925, 932 (1988) (analyzing the touch and concern doctrine in covenant law for whether it "serves as a useful limitation on the parties' ability to create burdens that will bind nonparties").

28. For a discussion of the public policy defense, see generally Stewart E. Sterk, Enforceability of Agreements to Arbitrate: An Examination of the Public Policy Defense, 2 CARDOZO L. REV. 481 (1980).

29. See, e.g., Roderick M. Hills, Jr., Back to the Future? How the Bill of Rights Might Be About Structure After All, 93 Nw. U. L. REV. 977, 978 (1998) (discussing the conventional wisdom regarding the rights/structure paradigm and Akhil Amar's textual and historical attack on it).

30. Compare 17A AM. JUR. 2D Contracts $\S 279$ (2004) (stating that unconscionability is found when "the inequality is so strong and manifest as to shock the conscience and confound the judgment of any person of common sense"), with 16B AM. JUR. 2D Constitutional Law $\S 970$ (2009) ("Due process can serve as . . . a check on official 
capacious enough to include within them a great many more specific rights. ${ }^{31}$ After developing the public/private "atomic arguments" in the next Part, I will show that the model permits us to see these doctrines as manifestations of the same underlying principle.

In addition to unifying private and public Constitutional Law, the model illustrates a gap in our understanding of Constitutional Law on the public side. Just as we have not fully appreciated the Constitutional Law heritage embedded in the study of "contract law," we have under-appreciated how much of judicial practice and custom on the public side is actually Constitutional Law. What governs a court in evolving the common law if not some, often unstated, metarules concerning the manner in which it may do so? This, too, is Constitutional Law: a common law, customary set of rules every bit as important but far less scrutinized than the written edicts that control the form and procedures of legislatures.

Although what constitutes valid legislation is defined by the Presentment Clause and its state, local, and administrative analogues, ${ }^{32}$ there is no written definition of legitimate, common-law rulemaking or judicial interpretation. At least, there is no centralized, easily digestible code for it. We have instead stare decisis, fit and justification, rules about deciding no more than is necessary, and a host of other informal doctrines, not to mention academic study. The model points toward a much richer understanding of the field of Constitutional Law than is usually connoted by that label. This is only a preview, and I take up further implications of the model for both Constitutional Law and Procedure in Part IV.

\section{The Institutional CALCULUS}

The model described in the last Part is, thus far, purely formal and descriptive. It is a lens through which legal systems are revealed as fundamentally ordered by choices between public and private decisionmaking. There is immediate intuitive appeal to this understanding, as it aligns nicely with the traditional categories that

misconduct which infringes on a fundamental right or as a limitation on official misconduct which, although not infringing on a fundamental right, is so literally conscience-shocking, and hence oppressive, as to rise to the level of a substantive due process violation.").

31. See McDonald v. City of Chicago, 130 S. Ct. 3020, 3030-36 (2010) (describing the history of the Supreme Court's use of the Due Process clause to incorporate many of the right in the Bill of Rights against state governments).

32. Note here that the law governing the authority of administrative agencies to make law is also Constitutional Law in my scheme. The Administrative Procedure Act and the opinions interpreting it are an important part of this law. See generally Administrative Procedure Act, 5 U.S.C. $\S \S 551-59$ (2008). So too are state zoning enabling acts and other "laws" that govern how subgroups within the collective can make laws. 
define legal education and practice. But the model is more than a handsome portrait of the law. It represents a way to unify legal analysis around basic, trans-substantive principles that take on specific and familiar forms when applied to particular instances of decisionmaking. This is so because the taxonomy renders legal systems as divisions of control between the most elemental of institutions: the public and the private.

This institutional description of legal systems converts what have often been understood as substantive problems into questions of institutional competency. Thus, it does for law as a whole what the legal process scholars did for understanding the roles of agencies, courts, and legislatures. Instead of asking what kinds of laws are truly "criminal laws," we can ask whether a given legal duty and purpose is best enforced by public or private prosecutors and whether its specification is best left to public or private lawmakers. We do this not with an indeterminate, ontological inquiry into the true nature of the law at issue, which I call the "historical-substantive" approach, but with a comparison of the relative competencies of private entities and public actors in carrying out that law's project.

In Robertson $v$. United States ex rel. Watson, for example, dissenting members of the Court reasoned that "criminal contempt," by virtue of its substance and traditional classification, is a "criminal law" and that because of this fact it cannot be enforced by private citizens. ${ }^{33}$ The taxonomy gives us an understanding of legal systems that replaces this formalistic inquiry with a functional one. It empowers us to ask directly whether private citizens can prosecute such actions with the requisite competencies. Indeed, as I argue below, the enforcement of some restraining orders, like the one in Robertson, may be a power located in a public/private "zone of twilight," in which private parties should have concurrent power to prosecute when public authorities choose not to do so. ${ }^{34}$

The institutional perspective also permits us to understand law in terms of higher-level principles than does the traditional "categorization by substance" approach. It frees us from the current landscape of fragmented, subject-specific grants of and limitations on power that are applicable only within seemingly sui generis legal

33. 130 S. Ct. 2184 (2010) (Roberts, C.J., dissenting). The Court dismissed certiorari as improvidently granted. Chief Justice Roberts wrote a dissent, joined by Justices Scalia, Kennedy, and Sotomayor, arguing that the Court should have reversed the Court of Appeals and held, as a constitutional matter, that criminal contempt may not be prosecuted by a private individual. Id. at $2190-91$.

34. See infra Part IV.A. Cf. Youngstown Sheet \& Tube Co. v. Sawyer, 343 U.S. 579, 637 (1952) (holding that in the absence of positive congressional grants of authority or prohibitions, the President operates within a "zone of twilight" in which congressional inactivity might practically invite presidential action). 
categories. Instead, we can describe a more basic set of principles that are generally stated but which take specific form after refraction through the public/private lens. For example, the taxonomy allows us to see that the doctrines of due process and unconscionability are distinct images of a general principle reduced to the fields of public and private lawmaking, respectively. Arguments built around these general principles and the competencies of the institutions they regulate are far more revelatory of our true concerns in lawmaking than are special-purpose principles apparently disconnected from other areas of law.

\section{A. Uncovering the "Atomic Advantages"}

In order to derive from the taxonomy the kinds of normative results just discussed, I will first describe an institutional calculus. This calculus comprises the basic tools we use in law to compare the competencies of any two institutions. As such, its uses go well beyond the mission of this Article. I will apply it here, however, only to compare the public as an institution with private entities as institutions.

Rather than produce an exhaustive list of arguments deployed when comparing institutions, I find it useful to identify core types of comparators. From these core, or "atomic," types, we can synthesize more complex arguments. By focusing on the atoms, though, problems of institutional choice can be reduced to more basic levels of analysis.

We can uncover atomic principles by tracing carefully what an institution is asked to do in order to reach and effect a decision, whether that decision be legislative, prosecutorial, adjudicative, or some other kind. I contend that institutions, generally, are tasked with taking account of the worth of decisional alternatives and carrying out the preferred alternative..$^{35}$ We can compare the relative advantages of institutions by focusing on their abilities to make and effect a decision. This involves taking account of information, aggregating the information, and effecting the preferred choice. Focusing individually on these decisional steps gives us the units of our institutional analysis. ${ }^{36}$

35. This need not be a consequentialist exercise. An institution may be expected to choose a result that will produce objectively "worse" consequences for the collective, but that is somehow deemed, collectively, more worthy. Of course, collectives often will be most concerned with whether an institution makes decisions that yield the most desirable consequences.

36. In fact, these steps result in a decomposition of a general social welfare function, focusing on estimation of its inputs and on its calculation. Because I assume the inclusion of non-individualistic inputs and no particular form of calculation, the theory here is not bound to consequentialism, welfare maximization, or any other normative theory. 
All decisions require inputs and the resources both to gather and assess the inputs and to effect the decision. Beginning with the inputs themselves, we can characterize them as either having to do with the preferences of individual members of the collective or not. To take proper account of individual-preference inputs, the institution must be able to assess those preferences competently. I call this "private calculation competency."

If, in contrast, a decision depends on factors that are not reflected in individuals' preferences, then these factors must be related only to the collective good. I call the capacity to estimate these nonindividualistic preferences "public calculation competency."

Next, these inputs must be used somehow to evaluate alternatives. They will need to be weighed, ordered, or otherwise processed to reach a decision. I call the capacity to use the inputs according to the will of the collective "public aggregation competency." This is the competency to take all of the inputs and from them to evaluate the worth of a course of action that coheres with the collective's evaluation.

There is a kind of aggregative competency that is so often at issue when comparing public and private decisionmakers that it is worth considering separately. I will call "distributive competency" the capacity of an institution to act as if it has as much concern for the preferences of another individual as it does for its own members'. A perfectly, distributively competent institution will not impose unjustified external costs, because its members act as though they have internalized the costs. ${ }^{37}$ No group, however, is perfect. But on some questions an institution may act as if it is. The more the consequences of a group's actions are restricted to the group itself, the more distributively competent that group is likely to be. But we will return to what makes a group more distributively competent and to the idea of relative competence below.

While the distributively perfect institution acts no differently than it would if each detriment it imposed fell on its own members, this does not mean that it aggregates preferences in a manner that treats all equally. It only means that to the extent some preferences are counted for less or not at all it is because the collective good otherwise demands it, not because of the selfish motivations of the institutions' members.

37. I use the term "distributive" here to indicate that it is a measure of an institution's members' ability to act as though they were in Rawls' "original position," that is as though they were ignorant of their own positions in society and in particular whether and to what extent they would be affected by the decisions they make. See generally JOHN RAWLS, A THEORY OF JUSTICE (1971). 
Finally, the ability actually to carry out the most worthy choice, I call "resource competency." Institutions might not only have differing financial resources to marshal when effecting a decision, but they may also possess qualitatively distinct powers for doing so. For example, public laws can be made that have coercive effects on an entire society, but private individuals generally must gain consent through contract to bind others. The ability to coerce more cheaply is an example of a distinct resource advantage.

With these atoms in hand, we can compare institutions by assessing their relative competencies. When one institution is more competent than another with respect to one of these atoms, we can say that the institution has an advantage. And so, in sum, when comparing institutions we inquire which has the relative (a) private calculation advantage, (b) distributive advantage, (c) public calculation advantage, (d) aggregation advantage, and (e) resource advantage.

Put differently: Are the decisionmaking candidates good at estimating the decision's impact on others, unselfish within the context of the decision, able to assess collective and nonindividualistic values, able properly to aggregate the relative inputs, and able to effect the decision? These are the atoms from which more complex institutional arguments are made.

It is important to note at the outset that these atoms do not inherently set out a deterministic arithmetic that will resolve in an uncontested fashion the proper institution to decide any conceivable issue. In a given legal dispute, we will not be able to measure each atom under some universal metric and then without controversy compare the resulting numbers to establish the proper choice. Producing a complicated argument to tell all societies what must be done is not the project of this Article.

Rather, the combination of reducing some important legal decisions to a choice between public and private institutions and identifying the basic components of institutional comparisons (including those between the public and private individuals) will yield a simplified account of legal choices across many seemingly disparate fields of law. The atoms remind us of the variables to analyze when comparing institutions, and they reduce complex arguments to more basic disagreements. For example, comparisons of complicated institutions can be simplified to questions of the proper weighing of preferences and to empirical information concerning, say, a decision's impact on an individual. But the way a collective chooses to balance a private actor's slight distributive disadvantage against a collective's poor understanding of the actor's preferences is a normative decision. Different societies will choose to conduct such balancing differently. What this periodic table of basic arguments 
does, however, is to reduce what appear to be complex, norm-bound, public decisions to much more basic, but still norm-bound, choices.

\section{B. Application to the Public and the Private}

The atoms are basic units of analysis that can be used to compare institutions. But they take on more specific meanings when restricted to comparisons between public and private institutions. They also possess certain default biases in favor of public and private control.

\section{Private Calculation Advantage}

Consider, first, private calculation competency. There is reason to suspect that individuals themselves will usually have a private calculation advantage over others, including the public. ${ }^{38}$ That is, generally an individual is better than others at determining how valuable something is to him or her. ${ }^{39}$ Where, however, some others have a private calculation advantage over an individual, and where we let the others' calculation advantage control for that reason, we have engaged in paternalism. ${ }^{40}$ We have substituted others' judgment concerning the worth of the thing to an individual for the individual's own judgment. Determining whether an individual or group of individuals has a private calculation advantage over a public institution is not always straightforward, as individual preferences may be predictably or unpredictably mutable in time, ${ }^{41}$ dependent on uncertain future events, ${ }^{42}$ and otherwise difficult to apprehend. ${ }^{43}$

38. See Frank H. KNIGHT, RISK, UNCERTAINTY AND Profit 77 (1921) ("Every person is the final and absolute judge of his own welfare and interests."); John C. Coffee, Jr., Does "Unlawful" mean "Criminal"? Reflections on the Disappearing Tort/Crime Distinction in American Law, 71 B.U. L. REV. 193, 225 (1991).

39. See, e.g., Coffee, supra note 38 , at 225 (suggesting there is a private calculation advantage in an individual determining the costs and benefits of deviating from socially desirable behaviors).

40. See Anthony T. Kronman, Paternalism and the Law of Contracts, 92 YALE L.J. 763,763 (1983) ("In general, any legal rule that prohibits an action on the ground that it would be contrary to the actor's own welfare is paternalistic."). For an overview of the proposals to restrict individual choice in the market and law-making process, see Jeffrey $\mathrm{J}$. Rachlinski, The Uncertain Psychological Case for Paternalism, 97 Nw. U. L. REV. 1165, 1177-1206 (2003) (arguing that cognitive errors may support constraints on the role of individual choice). But see Jonathan Klick \& Gregory Mitchell, Government Regulation of Irrationality: Moral and Cognitive Hazards, 90 MINN. L. REV. 1620, 1624 (2006) (questioning "the generality of the claim that short-run inefficiencies associated with psychological biases justify paternalistic government regulations").

41. For example, Carl Schneider describes the contextual dependence of private preferences for condom use. See Carl E. Schneider, After Autonomy, 41 WAKE FoREST L. REV. 411, 422-23 (2006). People may staunchly resolve to use condoms to avoid disease and pregnancy. However, "such resolutions often break down in the "heat of the moment.' Id. at 423 (quoting George Loewenstein \& David Schkade, Wouldn't It Be Nice? Predicting Future Feelings, in WELL-BEING: THE FOUNDATIONS OF HEDONIC PSYCHOLOGY 85, 93 (Daniel Kahneman et al. eds., 1999)). And the value of the resolution may skyrocket soon 
Furthermore, whether a calculation is "superior" depends on a normative balance between cost and accuracy. Deeper reflection and more study may lead to more accuracy but at an unacceptable cost. ${ }^{44}$ Logic will not resolve this balance, which is itself a matter of preference. All we can say without controversy is that if an individual can achieve a more accurate valuation at lower cost than others are practically able to achieve, then the individual has the private calculation advantage.

Where individuals are likely to be good evaluators without much effort, they will typically have a private calculation advantage over others. Where error costs are low for a broad range of error, again individuals are likely to have the advantage, as they can usually make decisions concerning their own tastes and circumstances more cheaply than others. But for truly consequential decisions, where the error costs are potentially significant enough that the costs of evaluation necessary to reduce them become practical to bear, the case for paternalism begins to come into focus.

\section{Distributive Advantage}

A reason often given to prefer public rather than private power over a decision is that the private decision would be selfishly, but not wrongly, calculated. In other words, people often, though not always, care more about themselves than about others. ${ }^{45}$ While we can rely on $A$ to do what is best for $A$, if we want to reach a decision that is

after the "heat" has dissipated. Id. at $\mathbf{4 2 2}$ ("In brief, we struggle ineptly to predict our own tastes, behavior, and emotions even over short periods and under familiar circumstances. We make systematic mistakes in anticipating what we will enjoy. We regularly 'miswant.'"); see also George Loewenstein et al., Projection Bias in Predicting Future Utility, 1 (Univ. of Cal. Berkeley Econ., Working Paper No. E00-294, 2000), available at http://papers.ssrn.com/sol3/papers.cfm?abstract_id=239901 ("Far more than suggesting merely that people mispredict future tastes, this projection bias posits a systematic pattern in these mispredictions which can lead to systematic errors in dynamic-choice environments.").

42. See KNIGHT, supra note 38, at 4. (noting that past experience only "give[s] us statements of what 'tends' to hold true or 'would' hold true under 'ideal' conditions").

43. For an excellent set of examples demonstrating just how mistaken a judge of our own preferences we can be, see Schneider, supra note 41, at 421-24.

44. While it is obvious that the cost of gathering information may exceed the marginal benefit it provides to preference formation and decisionmaking, it is also true that acquiring information can be costly in and of itself. See George Loewenstein \& Ted O'Donoghue, "We Can Do This the Easy Way or the Hard Way": Negative Emotions, SelfRegulation, and the Law, 73 U. CHI. L. REV. 183, 201 (2006) (noting that "information can impose real costs, especially when it ultimately doesn't change behavior"); see also Christian Turner, The Burden of Knowledge, 43 GA. L. REV. 297 (2009).

45. See, e.g., Lee Anne Fennell, Common Interest Tragedies, 98 Nw. U. L. REv. 907, 920 (2004) (observing that a "mismatch between internalized and actual costs and benefits skews a decisionmaker's assessment of whether a given action is beneficial, and can lead to inefficient choices about resource use"). 
best for the public at large, $A$ may not be the one to do it. After all, he might not take full account of the harm to $B$.

This is nothing more than a description of how an external cost, or externality, can lead to socially inefficient behavior. It is a stereotypical case for public regulation. ${ }^{46}$ For example, nuisance law represents an effort to prevent individuals from imposing inefficient, uncompensated costs on others' use of property. Without it, a polluting factory may selfishly decide to operate based only on the costs and benefits to it, without regard for the harms it imposes on neighbors-even if it knows what those harms are.

Externalities alone are not always justification for public decisionmaking, however. The public is not automatically distributively perfect, itself comprising agents whose decisions might be disadvantaged compared to individuals or subgroups. ${ }^{47}$ For example, democratic majorities, not to mention an autocratic dictator like Rex, ${ }^{48}$ sometimes make decisions that place higher values on the combined welfare of the decisionmakers and their constituents, while discounting the welfare of outsiders. ${ }^{49}$ The entire theory of using counter-majoritarian institutions to protect discrete and insular minorities is premised on the existence of such public externalities.

\section{Public Calculation Advantage}

Just as private individuals are normally thought to be best positioned to calculate their own preferences, we might suspect the public is better positioned to calculate public preferences that are not mere aggregations of private preferences. Although it is possible to argue that any public preference must be some combination of the preferences of those who compose the public, I leave this question open. ${ }^{50}$ In any event, it may be more convenient to segregate

46. See, e.g., Howard Beales, Richard Craswell \& Steven C. Salop, The Efficient Regulation of Consumer Information, 24 J.L. \& ECON. 491 (1981) (explaining the interest in regulatory techniques to protect consumers from inefficient buyer behavior). But see Paul L. Joskow \& Richard Schmalensee, Incentive Regulation for Electric Utilities, 4 YALE J. ON REG. 1, 12 (1986) (arguing that "regulators are not generally very good at distinguishing efficient from inefficient behavior; they simply do not have the information necessary to detect all flawed decisions").

47. Cf. Eric A. Posner, Law, Economics, and Inefficient Norms, 144 U. PA. L. REV. 1697, 1723 (1996) ("[T]he large size of the populations governed by state agencies means that some individuals will have no incentive to protest laws that injure them slightly, leading to attempts by interest groups to obtain redistributive laws.").

48. See supra note 17 and accompanying text.

49. See, e.g., John HaRT Ely, DEMOCRACY AND DISTRUst: A THEORY OF JUDICLAL REVIEW 151-54 (1980) (describing the heightened judicial review of laws burdening minorities as a response to the lack of minority representation in the democratic process).

50. See, e.g., Louis Kaplow \& Steven Shavell, Any Non-Welfarist Method of Policy Assessment Violates the Pareto Principle, 109 J. POL. ECON. 281 (2001) (showing that a 
preferences that concern collective well-being from those private preferences that are more selfish.

One example I will cite here, and to which I will refer briefly below, is a public preference concerning obligations to future generations that might conflict with the vast majority of individual preferences that would discount such preferences. ${ }^{51}$ Such discounting, in the face of a contrary public preference, would amount to intertemporal distributive disadvantage.

\section{Aggregation Advantage}

It is important to distinguish the more general aggregation advantage from what I have called the distributive advantage. $A$ has a distributive disadvantage with respect to $B$ if $A$ selfishly gives lesser weight to what $A$ believes are $B$ 's preferences than to his own preferences. But even if $A$ is unselfish, $A$ may aggregate his and $B$ 's preferences, which are obviously two-fold, into a new, single preference as to whether to go forward with an action in a different manner than the collective would aggregate those preferences.

For example, if Rex rules the collective, $A$ 's and $B$ 's preferences are irrelevant: only Rex's preferences count in reaching a decision. Another society might decide that for certain issues $A$ 's preferences, however strong, are of less importance than $B$ 's and so should not be weighed as heavily in resolving them. In each case, A's calculation differs from the public's even though $A$ perfectly calculated $B$ 's welfare and unselfishly weighed it (i.e., $A$ possessed both private calculation and distributive competency). This is what it means for $A$ to have an aggregation disadvantage. ${ }^{52}$

Calculating the aggregate public good requires knowledge of that good and the ability to calculate its prerequisites. Rex the Tyrant invariably has the aggregation advantage, as any consideration but his own wants is immaterial. In contrast, a society that calculates the good as some function of individual welfares faces a more complex question. When an action affects only a few members, and hard

calculation of social welfare that is not solely some function of individual welfares will lead to social choices that are inferior for every individual).

51. See, e.g., David Pearce et al., Valuing the Future: Recent Advances in Social Discounting, 4 WORLD ECON. 121, 122 (2003) ("W]e do discount future lives, both in terms of our own lives, and the lives of people yet to come."); Daniel A. Farber \& Paul A. Hemmersbaugh, The Shadow of the Future: Discount Rates, Later Generations, and the Environment, 46 VAND. L. REV. 267, 295 (1993) (citing empirical studies on discounting).

52. To give one other, somewhat trivial, example, even if $A, B$, and the public used the same numerical method of evaluating individual welfares, $A$ and $B$ might measure their joint gain by the sum of their individual gains, while the public might use another common measure: the square root of the sum of the squares of their gains. This mathematical difference will lead to different judgments concerning superior outcomes. 
choices about how to integrate their welfare gains and losses with the rest of society's are thus avoided, individuals will likely have an aggregation advantage, at least when they have private calculation advantage and distributive advantage. This is the case, for example, with a sale of goods between two parties that carries no significant externalities. In contrast, the more people who are affected by an action, the less likely it is that we will be able to identify a subgroup of the collective that has distributive and private calculation advantages over the whole public. It is also less likely that the impact of the many individual welfare changes on the public good will be easy to measure.

\section{Resource Advantage}

The public as a whole often has, through taxation, better access to the capital necessary to realize an action, and so the public often has a resource advantage over its private constituents. This may not always be the case, however. In practice, the resource question will turn on the precise circumstances of the relevant public and private entities. $^{53}$ For example, whether public or private prosecutors are best resourced to enforce publicly formulated safety regulations depends on the total context of the society in which the regulations exist. Are punitive damages available? Are private attorneys permitted to keep a large share of any awards? Are there enough potential actions to capitalize private prosecution firms? Is there an existing and large enough network of public prosecutors, perhaps with existing responsibilities in similar areas of enforcement, to take advantage of economies of scale? ${ }^{54}$

53. See, e.g., David Luban, Are Criminal Defenders Different?, 91 MICH. L. REv. 1729, 1735-36 (1993) (arguing that prosecutors have massive resource advantage over indigent defendants at trial); L. Harold Levinson, The Public Law/Private Law Distinction in the Courts, 57 GEO. WASH. L. REv. 1579, 1582-85 (1989) (giving examples of civil and criminal trials where either the plaintiff/prosecution or defendant has the resource advantage).

54. For an example in our own system of the possible inferiority of public resources to enforce law, consider laws that provide for private attorneys general. Surveying the area, Trevor Morrison identifies the major policy argument supporting such private attorneys:

[P]rivate attorneys general are depicted as a cost-effective means of supplementing resource-constrained public enforcement. As Frederick Schauer and Richard Pildes have observed in a related context, "[l]aw whose effectiveness depends on constant monitoring and enforcement by government officials will, absent massive commitment of public resources, be far less effective than law that can enlist social norms or private incentives to assist in enforcement."

Trevor W. Morrison, Private Attorneys General and the First Amendment, $103 \mathrm{MICH}$. L. REv. 589, 608 (2005) (quoting Frederick Schauer \& Richard H. Pildes, Electoral Exceptionalism and the First Amendment, 77 TEX. L. REv. 1803, 1831 (1999)). 
Even when access to capital is not an absolute constraint on private action, understanding how entities will weigh potential costs is not straightforward. Because of the declining marginal utility of dollars, the same outlay of, say, cash will not be considered an equal cost to two entities of radically different wealth. If we somehow knew that an action (prosecution or law-making, for example) was socially desirable, then we would want to put responsibility for the action on the entity most likely to conduct it. Accomplishing the action is assumed here to be a social good. Between two entities that would realize roughly the same absolute benefits and be faced with the same explicit resource outlays from the action, putting responsibility on the wealthier entity would be justified as consonant with that entity's resource advantage over its poorer companion.

But resource advantage is broader than a wealth advantage. The resources helpful to effect a decision include other rights and capacities. For example, the ability to threaten another party with damage, by withholding benefits or imposing punishment, is not evenly distributed within the private sector or between the public and private sector. An employer can coerce with the threat of discharge. A business partner can coerce with the threat of discontinuation of business. An enemy can coerce with the threat of blows or other attacks. Accomplishing an action often requires the cooperation of others, and public and private entities are rarely equally situated in their ability to garner that cooperation.

A party has a resource advantage with respect to a decision over another if it is better able to gain the necessary compliance of others in the decision. Often, we might expect the public to possess this kind of coercive advantage, as it has an important resource it normally denies private parties: the ability to threaten violence for noncompliance.

Just as with capital, however, it is only a tendency, and even then only for certain kinds of publics, that this kind of resource is more abundant in the public sphere. A private entity surely could coerce more successfully than the whole public in certain situations. To cite but one example, in-laws in the backseat may be better positioned to prevent speeding than the relatively remote risk of a speeding ticket.

More generally, when private parties can efficiently make enforceable law between them, they can efficiently coerce each other. Private parties suffer a comparative disadvantage to the public when they cannot efficiently make enforceable law between them. Thus we see that the inefficiencies typically lumped together as transaction costs are a source of private resource disadvantage. As they become higher, private parties are increasingly ill-equipped to coerce one another.

As a general matter, the public's relative resource advantage is often cited in arguments favoring public intervention. 


\section{Compound Arguments}

Before applying an institutional analysis to the taxonomy, it is helpful to observe how a few well-known analytical tools decompose into their atomic constituents and how direct analysis of those constituents is helpful in better understanding the problems at hand. I will assume from this point forward a collective that is concerned primarily, though perhaps not exclusively, with the private welfare of its members. ${ }^{55}$

\section{Transaction Costs}

A number of areas of public regulation have been justified as replacing what would otherwise be very expensive private contracting. For example, tort suits for auto accidents obviate the need for individuals to contract ex ante with all other drivers to allocate the risk of accidents. ${ }^{56}$ Since most people, the argument goes, would contract for something like what the tort system provides, namely agreements to pay for negligently caused damage, the public authority's imposing such terms saves the costs of contracting without losing much of the benefit of private contracting. ${ }^{57}$ It is the extreme resource advantage of the public authority, in the form of coercive lawmaking capacity, where the individuals' private calculation disadvantage is modest (again, assuming we know whether and how most people would contract for accident compensation from negligent drivers) that makes this possible.

With the power to coerce comes the advantage of dictating terms. ${ }^{58}$ When one can dictate terms, one saves the cost of achieving consensus with regard to lawmaking. While it would also be possible to save the cost of consensus by somehow granting private parties the power to coerce without the unanimous consent of those affected,

55. The taxonomy, of course, also captures the legal system of Rex the Tyrant, but systems so far from our own are not my focus here.

56. See, e.g., Guido Calabresi, Torts-The Law of the Mixed Society, 56 TEx. L. REV. 519, 525 (1978); see also Keith N. Hylton, Property Rules and Liability Rules, Once Again, 2 REV. L. \& ECON. 137, 141 n.12 (2006) (noting that "coordination costs prevent parties from meeting to bargain before [a traffic] accident occurs").

57. I am not asserting that this argument is true, but a society might conclude that for its people it is.

58. See, e.g., Robert L. Hale, Coercion and Distribution in a Supposedly Non-Coercive State, 38 POL. SCI. Q. 470, 471-73 (1923) (arguing that property law effectively provides the coercive power that allows an owner to dictate the terms on which a non-owner can use or consume the owner's property); Robert L. Hale, Law Making by Unofficial Minorities, 20 COLUM. L. REV. 451, 452 (1920) (characterizing contracts as creating legal rights and duties "by virtue of the power of mutual coercion (in the form of pre-existing rights) vested by the ordinary law in the two contracting parties" and noting that when one party holds rights and privileges of superior strategic importance "the other party may in effect be compelled to submit by contract to almost any terms imposed by the stronger party"). 
such parties are generally, though not always, at a severe distributive disadvantage-meaning that they severely undervalue the welfare of their adversaries-relative to the public at large.

Obviously, public decisionmaking carries costs, as private decisionmaking might have other advantages that will now be lost. ${ }^{59}$ But where private parties' private calculation advantages are modest, their distributive disadvantage severe, and their costs of obtaining mutual consent much higher than the cost of public lawmaking (i.e., their resource disadvantage relative to the public very high), we see that no atomic advantages significantly favor private lawmaking. The resource advantage, however, heavily favors public lawmaking. Therefore, in such situations, we should expect to find, and do find, public lawmaking. ${ }^{60}$ If we see private lawmaking, it should always be accompanied by innovations intended to reduce transactions costs and thus the private parties' resource disadvantage.

\section{The Tragedy of the Commons}

Garrett Hardin's iconic story of the tragedy of the commons is well-known. ${ }^{61}$ A cattleman in an open-access commons decides whether to put an additional cow on the common pasture by considering the benefits and costs to him of the marginal cow. Because the benefits are internalized but the costs of the extra cow, in the form of degraded rangeland, are spread over all the users, the cattleman may graze the extra cow even though the total costs imposed by the cow's grazing exceed the cow's benefits. ${ }^{62}$

Suppose this group of commons users had the means to cooperate as a coherent public capable of mutual coercion. Should the decision whether to put cows on the rangeland be made privately or should there be regulation by this public? How should it make this decision? First, there is little private calculation advantage favoring the

59. See, e.g., William A. Fischel, The Economics of Zoning Laws: A Property RightS APPROACH TO AMERICAN LAND UsE CoNTROLS 133-35 (1985) (discussing the transaction costs of public decisionmaking regarding land use decisions).

60. See supra note 56 and accompanying text (discussing the move from Contract to Tort for automobile accident compensation).

61. See Garrett Hardin, The Tragedy of the Commons, 162 SCI. 1243, 1244-45 (1968).

62. Id. at 1244. Hardin's original description is beautifully concise:

[T] he rational herdsman concludes that the only sensible course for him to pursue is to add another animal to his herd. And another; and another. . . But this is the conclusion reached by each and every rational herdsman sharing a commons. Therein is the tragedy. Each man is locked into a system that compels him to increase his herd without limit-in a world that is limited.

Id. 
cattlemen as individuals. Though they likely have cheapest access to the information concerning the values to them of grazing additional cows, these values are not especially idiosyncratic. A disinterested observer could probably calculate the private benefit of grazing an additional cow nearly as well as the cattleman himself. Note that this also means that each cattleman is probably not a bad calculator of the value of grazing to the other cattlemen. So neither the public nor the individual cattlemen appear to have any significant private calculation advantage.

It is similarly doubtful that the cattlemen have any advantage, or disadvantage, in public calculation or aggregation. In an economic commons, if we restrict attention to exploitation, there is probably not much disagreement about the total benefits to all users or that that total is a sum of private benefits.

Where the individual cattlemen lose out is in their extreme distributive disadvantage. Hardin's famous example would not occur if each cattleman felt the damage done to fellow commons users as strongly as damage done to himself. In that case, there would be no true externality. But a tragedy of the commons occurs when users discount the happiness of others. Although one of our cattlemen is not at a particular disadvantage in estimating the harm to his peers caused by grazing one more cow, he values that harm less than he would if it were his own. ${ }^{63}$ This distributive disadvantage will lead to inefficient private choices, and in the case of an open access commons, a cascade of inefficient choices.

Further, the private users will have difficulty combining to form an advantaged private entity. In more familiar terms, the users will have a difficult time contracting, as in the prior example. Here, this difficulty arises because they cannot effectively keep out new users, with whom they must also contract. As the number of potential users increases, private contracting becomes more expensive and therefore less attainable. The public often has a decided resource advantage here, as it can more easily dictate terms that apply to large numbers of users and potential users. ${ }^{64}$

63. Hardin describes the cattleman's distributive disadvantage in terms of his selfish calculation of the marginal utility of adding a cow. Id. The cattleman asks, "What is the utility to me of adding one more animal to my herd?' " Id. In doing so, he discounts completely the damage to his peers.

64. The point is not that open access commons will never be susceptible to private ordering. Rather, inherent in such commons are these problematic tendencies. Private ordering may effectively avert the tragedy when private entities are comparably resourced to public entities with respect to creating coercion sufficient to overcome their individual distributive disadvantages. See, e.g., ROBERT C. ELLICKSON, ORDER WITHOUT LAW: How NEIGHBoRs SETTLE DISPUTES 237-39 (1991) (arguing that close-knit groups "have] both continuing reciprocal power over one another and also a bank of shared information," 
Using the atomic advantages, we can predict situations in which the tragedy of the commons will not so obviously point toward public regulation: namely, and contrary to Hardin's hypothetical scenario, when the individual users do have a significant private calculation advantage. It becomes even more difficult, politically, when there are public preferences distinct from and possibly in competition with the private preferences of the commons users. This is so because there is likely to be internal disagreement about how to measure such public values and how to aggregate them with the users' preferences. Indeed, the more difficult commons problems arise where: (a) the benefits derived from the commons are highly idiosyncratic and difficult to estimate, so that the public is at a large private calculation disadvantage even as it is advantaged in other dimensions and (b) where the social good of the commons is highly divergent from the good as understood by many commons users, putting private entities at a likely public calculation disadvantage, predictably resulting in political friction.

The market in pollutants that contribute to climate change comes to mind as just such an example, owing to the diversity of uses that occasion such pollutants and the degree to which those activities are psychologically distant from the ultimately tragic consequences. ${ }^{65}$ Here, users' preferences are not well correlated with collective concerns, which may seem distant, resulting in predictable fighting over the true weight of those concerns and over how to weigh them against the much more readily apparent private benefits of use. Taxation seems like it would solve both problems, by internalizing the social cost without displacing private cost-benefit calculations. In

attributes that reduce resource disadvantage relative to public enforcement mechanisms). In addition to his own research on the ranchers of Shasta County, Ellickson cites James Acheson's pathbreaking work on informal social ordering among Maine lobstermen. Id. at 238 n.23. Acheson observes that between the three extremes of unregulated individual exploitation of an open access commons, a fully propertized commons, and a fully regulated commons lie "communal property arrangements," meaning control by a nongovernmental collection of individuals. JAMES M. ACHESON, THE LOBSTER GANGS OF MAINE 143 (1988); See also ELINOR OSTROM, GOVERNING THE COMMONS: THE EVOLUTION OF INSTITUTIONS FOR COLLECTIVE ACTION 182-91 (1990) (summarizing empirical studies and their relationships to game-theoretic models concerning open access commons and establishing that under many assumptions private ordering will avert tragic misuse). Notably, to the extent private ordering responds to a tragedy of the commons, it results from a sub-society with its own, internal legal system, which itself is subject to the taxonomy advanced here. Private individuals form a "public" when they organize, even if imperfectly, their mutual coercive power. I leave the problem of pluralism, the view of society as a grand collage of sometimes hierarchical and sometimes parallel legal systems, for another work.

65. Another example that has been suggested to me is the market in health care. At the heart of both of these complex social problems lie basic decisions concerning public and private control that require an analysis of the competencies of the public and private as institutions. Understanding the problems this way helps to clear much of the fog from what our most basic disagreements actually concern. 
other words, it might preserve private calculation advantage while solving the private party's failure to internalize public preferences. By focusing on the atomic advantages that are behind the tragedy, we can better appreciate the types of open-access problems that are likely to be contentious and where users are likely to resist collectivizing solutions.

\section{Principal-Agent Problems}

As a third example, take principal-agent problems, which arise in most forms of public decisionmaking and in corporations. ${ }^{66}$ These problems come in at least two flavors: the problem of disloyal agents and the problem of misguided but loyal agents. Loyal agents may fail because of calculation disadvantages. Though they are tasked with representing a principal, perhaps a government official representing the public, they miscalculate the principal's wants. Whether it is a private preference or public norm that is miscalculated depends on whether the principal is private or public, respectively. Disloyal agents, by contrast, may or may not properly calculate the principal's preferences, but they are distributively impaired. They act at least in part on account of their own preferences in derogation of the principal's. ${ }^{67}$ For this reason, the problem of disloyal agents is often an instance of an arrangement with distributive disadvantage.

Most arguments concerning public and private competency can be translated to a composition of the elements I have identified here. For example, the public owes its advantage in eliminating transaction costs, where it exists, to its resource advantage combined with minimal or nonexistent calculation and distributive disadvantages. The tragedy of the commons presents a case of private distributive disadvantage combined with resource disadvantage. Agency problems result from either distributive disadvantage or calculation disadvantage.

With the tools in hand to analyze choices between public and private institutions, we can proceed to analyze legal systems as primarily ordered by basic institutional choices. These atoms will help us to understand the range of arguments concerning the

66. See, e.g., Michael C. Jensen \& William H. Meckling, Theory of the Firm: Managerial Behavior, Agency Costs and Ownership Structure, 3 J. Fin. Econ. 305 (1976), reprinted in 3 LAW AND ECONOMICS: OTHER AREAS OF PRIVATE AND PUBLIC LAW 107, 111 (Richard A. Posner \& Francesco Parisi eds., 1997) (noting that the principal-agent problem "exists in all organizations and in all cooperative efforts-at every level of management in firms, in universities, in mutual companies, in cooperatives, in governmental authorities and bureaus, in unions, and in relationships normally classified as agency relationships such as are common in the performing arts and the market for real estate") (citation omitted).

67. Id. at 110 ("If both parties to the relationship are utility maximizers there is good reason to believe that the agent will not always act in the best interests of the principal."). 
classification of law within the resulting taxonomy and the regulation of and within the categories themselves.

\section{IMPLICATIONS}

In Part II, I developed a taxonomy of legal systems constructed around discrete divisions of institutional control between the public and private actors. Part III established a language of institutional comparison that can be used to evaluate relative public and private competencies with respect to the basic decisions-lawmaking and enforcement-that underlie legal systems. By changing focus from historical-substantive definitions of legal subjects to functional, institutional ones, the taxonomy makes possible a great many innovations in our study of legal systems. It exposes the relevance of the techniques of the legal process school, and its descendants, for the entirety of legal structure, not just inter-governmental comparisons.

In this Part, I begin to explore some of these implications. In particular, there are three types of advancements that I wish to highlight. First, the taxonomy suggests basic principles, or transsubstantive rules, that take on their familiar forms when refracted through the lens of a particular taxonomic category. An example to which I have already alluded, and which I will elaborate below, is the connection between due process and unconscionability, which are particularized expressions of a more basic principle of institutional competency in Constitutional Law. I believe that such basic principles provide a more sensible way to understand our own Constitution and that our focus on particular provisions applicable to historical-substantive, rather than functional, categories has resulted in unnecessary confusion.

The taxonomic categories developed here are highly correlated but not perfectly co-extensive with our law's historical-substantive categories. Where there is imperfect overlap, there is an opportunity to observe whether the colloquial, substantively defined categories of our law have led us astray. After all, to the extent these categories depart from those of the taxonomy, the categorization is no longer serving the functional purposes discussed here and elides institutional differences between the public and the private. It should therefore come as no surprise that laws in this gap come into tension with a functional understanding of what our law should do. Tort suits for punitive damages and private actions to enforce "criminal" laws are two examples I will explore to illustrate this.

Second, the taxonomy highlights areas of our law that might otherwise seem ad hoc or sui generis. For example, the model explains why the law of charitable trusts appears primarily in the Parens Patriae category. When our legal system is viewed as a 
collection of historical-substantive categories, it seems a special case that the state attorney general enforces charitable gifts. The institutional model, however, explains why this is so and gives this area of law a structural role related to the other, more populated categories. The logical, structural map of the taxonomy serves as a reminder of the multitude of options available to us in crafting a legal system.

Finally, the model (a) makes transparent the relevant objects of study within legal systems and the modes of that study and (b) simultaneously exposes the relation between the scholarship of different fields. The taxonomy renders obvious the sorts of questions one would ask and the analysis one would use to compare, for example, property rules and liability rules or criminal law and tort. While the discussion of the first two implications goes a long way toward demonstrating this, I close with a further suggestion of the integrative possibilities of the public/private model. Calabresi and Melamed's distinction between property rules and liability rules is in fact a structural distinction between public and private control over remedies. This suggests a possible third dimension of our taxonomy, which I begin to explore. The unification of these concepts with the institutional calculus demonstrates further that formerly disparate areas of study can be unified as different applications of the same basic principles.

\section{A. Trans-substantive Principles and Constitutional Law}

The first major implication of the taxonomic method, and the one to which $I$ will devote the most attention here, is the symmetry it exposes between the secondary rules (Constitutional Law and Procedure) of the various legal subjects. If these subjects differ primarily in their choices of institutional actors, then so too should their secondary rules chiefly reflect the differences among these choices. My claim in this section is that there are general principles, independent of any of the specific categories, that translate into specific secondary rules when applied within the categories.

The two principles I develop here are: (1) an ex ante requirement that institutions be designed and their scope of authority crafted to realize atomic competency and (2) an ex post principle invalidating decisions that manifest extreme atomic disadvantage, i.e. poor institutional fit. The first principle guides the choosing and design of decisionmaking institutions in order to capture the usual advantages and mitigate the usual disadvantages of the institution's type (public or private). The second principle examines an institution's decisional output for manifest disadvantage despite the ex ante appropriateness of the institution for the kind of decision reached. In the remainder of 
this section, I will examine these principles in the context of Constitutional Law. In the next section, I will apply these two principles to Procedure to derive secondary rules concerning Criminal Law and Tort.

\section{The First Principle: Institutional Selection (Structure)}

Perhaps the most basic thing a legal system must do is to determine who will make its laws. Most systems will allow for a diversity of lawmaking bodies, with secondary rules that describe the necessary fit between the type of law made and lawmaking institution. I am concerned here with how legal systems determine, ex ante, whether an institution will be permitted to make laws of a given type. Such a principle is, again, one of fit. As such, it can be examined in two ways: (a) as a constraint on the kinds of law a particular institution is entitled to make or, equivalently, (b) as governing the attributes of institutions that make a particular law. To put it differently, it does not matter whether we conceive of this ex ante constraint on lawmaking as selecting the proper sort of laws for a given institution or the proper institutional form for a given law. They amount to the same inquiry.

The first principle, restricted to Constitutional Law, states that lawmaking institutions must possess the atomic competencies as lawmakers. This principle implies constraints on institutional design and on the scope of lawmaking authority. While an institution might be competent to make certain laws, it might be predictably incompetent at making other laws. In particular, public and private entities have stereotypical advantages and disadvantages, and lawmaking authority should be assigned in such a way as to control the stereotypical disadvantages while capturing the benefits of the advantages.

\section{Privately Made Law}

Given that public actions are consciously the work of the collective, one can argue for a sort of natural primacy of private control that relies not on any anthropological or psychological evidence, but on logic: "While private persons are agents in nature, the public has no natural manner of acting. . . That is why private agency is the presumptive and residual category, public agency the one that has to be established." 68 While it is possible to establish suffocatingly intrusive and powerful public agency, a collective must affirmatively decide that it will do so.

68. Stanley I. Benn \& Gerald F. Gaus, The Public and the Private: Concepts and Action, in PUBLIC AND PRIVATE IN Social LIFE 16 (Stanley I. Benn \& Gerald F. Gaus, eds., 1983). 
We therefore generally default to private lawmaking (and to private enforcement) except in those situations in which the atomic advantages clearly favor public institutions. ${ }^{69}$ In other words, we will prefer to allow the individuals within the collective to govern themselves when possible. The problem is that private lawmakers, again stereotypically, are disadvantaged in each atom save private calculation.

At a minimum, the first principle requires that lawmakers be selected so that they are relatively distributively competent. No institutions composed of humans will completely slip the bonds of selfishness, but we do not require perfection here. Private lawmakers should be empowered at least when they do not suffer distributive disadvantage relative to public lawmakers. A single individual with authority to make laws of his own choosing that bind others would very likely not make laws consistent with the public good. This individual will probably discount the preferences of others and aggrandize his or her own. The way to eliminate this disadvantage is to limit the lawmaker's scope of authority to those laws as to which others are indifferent, so that their preferences would be inconsequential even if the individual considering them were distributively perfect.

If a law would regulate the conduct only of those who agree to be bound by it, then enactment by these individuals will not suffer from significant distributive disadvantage. For this reason, the presence of consent among all those who could be coerced under a law is the primary constitutional identification-principle within private lawmaking.

If a private law has the consent of all those who will be regulated, meaning those subject to coercion after adjudication, then we conclude that the set of private citizens making the law has together calculated and fully valued all of the individual welfare effects of the law. ${ }^{70}$ After all, if a properly calculating person does not prefer a law, he or she will not consent to it. Collectively, this private group has no distributive disadvantage compared to any larger set of individuals or the whole public, even though the group's members may be

69. The point of this section's assumption is that the occasions are rare and therefore special, in such societies, when a distributively perfect and well-calculating group of individuals reaches a decision contrary to the public's will. Thus, well-calculating private individuals are usually at no public calculation or aggregation disadvantage. Since the relevant inputs in such situations often concern only the parties themselves, the parties' aggregation is usually preferable to those of any public agent.

70. It is possible, of course, that a private law may impose externalities on others who are not directly regulated by it. Reaching this conclusion requires us to scrutinize the law's content. Where a particular private law's content makes us highly suspicious that the atomic advantages, such as distributive advantage, are lacking despite the apparent consent of affected parties, we resort to the second principle, manifesting in Contract as the doctrine of unconscionability or a finding that the contract violates public policy. 
individually selfish, because no other individuals will be bound to follow any provisions of the private law.

Insisting on consent among the group regulated by a private law also provides some assurance that the group possesses the other atomic competencies. If a society is normally concerned with maximizing private welfare, or at the very least approves of legal changes that are Pareto efficient (in a broader welfare, rather than wealth, sense), then consent among affected parties ought generally to satisfy us that the private group has sufficiently aggregated preferences, ${ }^{71}$ since the public, too, would prefer a law that improved the lot of some private parties without negatively affecting others. To the extent a particular private law does not have this property but, instead, greatly harms private or collective interests, as to which private lawmakers do suffer both distributive and public calculation disadvantage, respectively, our second principle can be used to justify its invalidation. I will return to this below, but for now, and restricting attention to societies similar to our own, we can conclude that true consent to be bound among all those regulated will usually reflect an act of lawmaking that is not disadvantaged with respect to any atom relative to a public determination of the worth of the same law.

Thus, within Contract, the first principle will blossom into doctrines meant to guarantee consent among regulated parties. These doctrines are the structural rules of the Constitutional Law of Contracts. One method for ensuring consent is to require that private laws be accompanied by evidence of agreement by the affected parties, each of whom possesses private calculation advantage. From this follow the doctrines of offer and acceptance, competence to contract, the parole evidence rule, the statute of frauds, and more. They are, most importantly, a natural consequence of the institutional method the model illuminates. These doctrines measure, through consent, the atomic competencies of a private group to pass laws that will bind its members.

The strength and quality of the evidence of agreement necessary to recognize enactment of a private law, naturally, ought to be conditioned on the prevailing social circumstances with respect to the type of agreement at issue. How commonly, for a given sort of agreement, do people tend to claim agreement when there is none, whether fraudulently or out of confusion? What are the potential

71. Of course, "[l]eadership, charisma, and feelings of deference may give the preferences of one individual more weight in the process than the preferences of others." Michael E. Levine \& Charles R. Plott, Agenda Influence and Its Implications, 63 VA. L. REV. 561, 598-99 (1977). 
consequences if this sort of private law is made by atomically incompetent private entities?

If we insist on more or better evidence of consent, we are asking in effect for more elaborate lawmaking procedures. The goal of structural Constitutional rules is to ensure institutional competency, which reduces in Contract Law to ensuring consent among regulated parties. For some types of contracts, realizing this goal requires more procedure and perhaps even the observance of stricter institutional forms before recognizing "enactment." The Statute of Frauds is an example of a structural requirement that selects certain laws for the heightened procedure of written, rather than oral, enactment. Thought to be unusually prone to fraud and coercion, ${ }^{72}$ wills have even more elaborate enactment procedures aimed at measuring atomic competency, including a more elaborate institutional structure that requires the participation of witnesses (disinterested lawmakers who will not be regulated by the private law).

In contrast, the law of gifts requires only weak evidence of consent. $^{73}$ The making of a gift, as a private law transferring property, must still satisfy our first principle and thus must still be accompanied by the consent of the regulated parties. In the law of gifts, this consent is formally known as "acceptance" by the donee. ${ }^{74}$ Consent here serves the same purpose it does in other contracts: measuring agreement and thereby avoiding a distributively flawed and poorly calculating private law transferring the gift. But with respect to gifts, we generally require no affirmative evidence of acceptance. For gifts of objective value, courts presume acceptance. This is only a presumption, and so evidence of lack of a donee's consent will defeat a gift. But we assume that nearly everyone would accept a gift, meaning consent to a law transferring it to them, when the gift is valuable. Thus, insisting on more elaborate structure (procedures evidencing consent) is not worth its costs in this area of law.

The model suggests that to the extent the various forms of Contract Law insist on differing levels of proof of agreement, those differences should reflect the levels of skepticism the public has concerning the voluntary nature of the private group making the kind of law at issue. This is because voluntarism ensures, at least

72. See generally Ralph W. Gifford, Will or No Will? The Effect of Fraud and Undue Influence on Testamentary Instruments, 20 CoLUM. L. REV. 862 (1920).

73. For an overview, see generally Eric A. Posner, Altruism, Status, and Trust in the Law of Gifts and Gratuitous Promises, 1997 WIS. L. REV. 567 (1997).

74. Consent on the part of the donor is measured by an element requiring that the donor had an intent to make a gift and delivered that gift. 
from an ex ante, structural perspective, the relative atomic competence of the private entity to make law.

There is at least one area of Contract Law, though, where we again require more evidence to satisfy the first principle, but not evidence of voluntarism. Covenants that run with the land, essentially contracts that will bind successors in interest of real property who themselves were not party to the contract, require more than consent to become binding private law against such successors. Most of this evidence can be created by the original contracting parties, but the requirement that the agreement "touch and concern" the land is not an element that can be created by parties, no matter how desirous of creating a covenant that runs. ${ }^{75}$

With respect to this kind of contract, we see that the original contracting parties are not the only ones who will be regulated by the agreement. Therefore, consent between them, while important, is insufficient to satisfy the first principle. Indeed, those who will be regulated may not even be born at the time of the agreement. The original contracting parties thus have both distributive disadvantages and possibly public calculation disadvantages, to the extent they discount the welfare of future generations more than the public otherwise would.

The requirement that the agreement touch and concern the land attempts to ensure against these incompetencies by detecting whether, on average, these consenting parties are good agents for the future landowners who would be regulated. That is, does the selfinterest of the parties probably align with that of future landowners? If the contract relates to the parties' use of land, then perhaps, on balance and on average, the answer is yes.

This brief tour demonstrates how the simple, abstract first principle can explain the diversity of private law procedures and forms, once we understand the problem to be one of institutional competency.

\section{Publicly Made Laws}

Public lawmaking, the kind "that has to be established,"76 yields Tort and Criminal Law. It is appropriate where private lawmaking is insufficient to meet societal goals and where the public lawmaking institutions possess the requisite atomic competencies. We should remember that these categories are not exclusive with respect to legal goals. That is, we can and do use Contracts, Tort, and Criminal Law to regulate the same activities. Access to private property, for

75. Stake, supra note 27 , at $943-48$.

76. See supra note 68 and accompanying text. 
example, is governed by contracts, by trespass torts and by criminal trespass statutes. An intentional killing is both a breach of criminal statutes and a wrongful death tort. The basic principles can, however, help us to determine when an institutional configuration (a box in the model) should be the exclusive means to achieve a goal and when a configuration should be disallowed.

When applied to public lawmaking the first principle (ex ante, structural competency) results in a number of doctrines intended to ensure institutional form and methods of enactment that will result in atomically competent decisionmaking. Accomplishing this in the field of private lawmaking leads inevitably to the identification of consent among regulated parties as the linchpin of the requisite structural Constitutional Law. But public lawmaking seeks to solve social problems where such consent is not readily achievable, often because the costs of doing so, for example through mass contracting, are insurmountable. Public institutions must necessarily be freed from the demand the first principle places on private lawmakers that all regulated parties consent to any law.

Of course, the individual actors who make public laws are just as susceptible to distributive incompetency as private lawmakers, and they are just as prone to omitting collective, non-individualistic preferences when making decisions. Further, because they make law that will bind others without others' consent, we cannot be sure that the lawmakers have even measured individual preferences properly. Without consent, what does the first principle demand?

Lawmaking institutions are incredibly diverse, including traditional legislatures, local government bodies, administrative agencies, common law courts, and citizen electorates. It is obviously beyond the scope of this Article to trace the principle's specific action on every possible lawmaking structure, but I do have some initial thoughts.

The primary public Constitutional Law resulting from the first principle consists of (a) the affirmative structural requirements defining and granting powers to institutions and (b) procedural due process as a tool with which other public institutions can measure, ex ante and without reference to the lawmaking output of the institution, the success of these definitional provisions. With respect to the former, a study of lawmaking process rules as a cohesive whole has only just begun.

Adrian Vermeule is one of the relatively few that has tried to connect basic principles of institutional competency with the 
procedural rules of a lawmaking institution. ${ }^{77} \mathrm{His}$ attention was restricted to Congress and to some of the rules in our Constitution that define Congress and its methods. ${ }^{78}$ But the larger project was "to examine this body of rules as a unified topic that is central to the constitutional design of legislative institutions."79

Vermeule's method is similar to the one I advocate here: $\mathrm{He}$ identified "widely shared criteria" of success in institutional design and then used them to analyze the various procedural rules. The criteria he identified are nearly isomorphic to the atoms. ${ }^{81}$ With these, Vermeule surveyed various constitutional provisions concerning congressional procedure and analyzed them for, among other things, their tendency to prevent aggrandizing institutional acts, which he describes as opening the door to self-dealing (i.e. distributive failure), and to ensure enough participation in deliberation to ensure informed consideration (i.e. calculation competency). His is an instructive primer on the use of quorum rules, super-majority voting, open meetings, and the like to make the competency of the lawmaking body more likely.

Congress, of course, is not our only lawmaking body, and the structural rules necessary to ensure its competency are not likely to be identical to those needed for other bodies that have different missions and less visibility. Administrative agencies are established by the Administrative Procedure Act, their organic statutes, and court rulings. Subject to the outsized influence of interested parties, agencies are often required to go through procedures such as notice and comment before making law, an effort to ensure distributive advantage (securing against agency aggrandizement) and aggregative competency (securing against capture). Local land use planning is governed by state zoning enabling acts, often with special procedures to promote competency despite the nonprofessional and often conflicted composition of city and county commissions. Whether

77. See Adrian Vermeule, The Constitutional Law of Congressional Procedure, $71 \mathrm{U}$. CHI. L. REV. 361 (2004).

78. See id.

79. Id. at 363 .

80. Id. at 380 .

81. See id. at 381-82. Vermeule's criteria are (1) minimization of principal-agent problems, (2) encouragement of "well-informed and cognitively undistorted deliberation," and (3) efficient use of legislative resources. Id. The first principle is another way, as we have seen, of analyzing the distributive competency. See id. at 381 . The second measures, though lumping them together, the private and public calculation competencies. See id. The third measures the resource competency of an institution. See id. at 382-83. Perhaps because he did not focus on questions of structure and composition, id. at 362, Vermeule's principles do not obviously measure aggregative competency. But in representative bodies, it is often assumed that if the representation is "fair," a question of structure and composition, a well-calculating and distributively competent body will aggregate in a way that is by definition in the public interest. See id. 
judges are elected or appointed, for how long, and how their ruling are reviewed are variables that ought to be informed by the demands of the first principle.

The law of procedural due process is intended to review decisionmaking bodies themselves for adequate structure in light of an alleged harm. Courts use this secondary rule to examine a lawmaking institution for adequate procedure and form under the circumstances. ${ }^{82}$

With this understanding, it should be clear that procedural due process analysis is the twin of the consent principle in private lawmaking. Each is an ex ante measure of a lawmaking institution's structure for atomic competency. Once we recognize these doctrines' symmetric roles, we appreciate that Contract Law is shot through with its own version of procedural due process. ${ }^{83}$ There, the requirement of consent generated structural requirements that varied with our level of concern that, in a given area, voluntarism might be absent. In public law, procedural due process demands different levels of proof of lawmaker competency depending on the risk of otherwise uncorrectable incompetency in a given lawmaking area.

For formal, top-level legislatures, there is essentially no procedural due process review, not because the first principle plays no role, but because it is automatically satisfied by rule-like constitutional form and procedural commands. Many lower-level legislative bodies, however, do find themselves subject to procedural due process review. And just as with the measurement of consent, the degree of evidence required to demonstrate competency, satisfying the first principle, varies depending on experience-based estimates of the frequency with which a given type of institution administering a particular kind of law will lack atomic competencies.

For example, in administrative law, agency lawmaking that can be characterized as "adjudication," basically laws that apply to deprive "[a] relatively small number of persons" of important interests, are subject to more stringent ex ante procedural requirements. ${ }^{84}$ Agency actions that work similar deprivations on broader classes are more likely to be deemed legislative and to be subject to lesser procedure. ${ }^{85}$ The first principle applies in the same

82. See Wallace Mendelson, A Missing Link in the Evolution of Due Process, 10 VAND. L. REV. 125, 135 (1956).

83. Those who have advocated for a new role for procedural due process in private law have, therefore, actually been arguing for greater levels of competency proof, not so much for a qualitatively different set of private secondary rules. See, e.g., F. Eric Fryar, Note, Common-Law Due Process Rights in the Law of Contracts, 66 TEX. L. REV. 1021, 1026 (1988) ("Unlike lawmaking and substantive limits, however, due process limits play a relatively minor role in regulating contractual self-government.").

84. Bi-Metallic Inv. Co. v. State Bd. of Equalization, 239 U.S. 441, 446 (1915).

85. See 2 RICHARD J. PIERCE, ADMINISTRATIVE LAW TREATISE 737-44 (5th ed. 2010). 
way in local government law ${ }^{86}$ Just as we measure for consent as a proxy for calculation and distributive competency in private law, broadly targeted laws are more likely to visible among the public agents' constituents, and so we worry less that they are severely miscalculating the preferences of the affected parties or that they are self-dealing, i.e. distributively incompetent.

\section{The Second Principle: Manifest Ml-Fit (Rights)}

An ongoing and central debate in our contract law concerns the extent to which the sovereign, whether through legislatures or courts, should impose public norms of fairness on private agreements. In other words, how deeply should the substantive constraints on private lawmaking go? A homomorphic debate rages within public law, from the Supreme Court in Roe v. Wade, ${ }^{87}$ to the Court in Lawrence v. Texas, ${ }^{88}$ to the dissenters in Kelo v. City of New London. ${ }^{89}$ Each of these opinions represents an effort to use Constitutional Law to find implied substantive constraints on what another lawmaker within the system is able to do.

The second principle grounds this objective in an examination of an institution's decisional output for evidence of aberrantly poor fit, i.e. unusual atomic disadvantages. A legislature may be defined by rules intended to select its members, guide its functions, and vest it with authority in a manner to preserve atomic competencies. That is, the legislature is governed by Constitutional Law derived from the first principle. And yet, it may nonetheless engage in self-dealing or act contrary to the will of the public. The second principle is meant to detect these failings.

Under the second principle, when a law manifests the significant lack of atomic competencies it will be declared invalid. So contracts manifesting unusually poor private calculations or tort or criminal laws demonstrating peculiarly poor public calculations or unusually bad distributive consequences will, at some point along the spectrum, be deemed to go too far and will not be enforced. In other words, manifest institutional failure will be the basic criterion of invalidity. ${ }^{90}$

86. Bd. of Cnty. Comm'rs v. Snyder, 627 So. 2d 469, 474 (Fla. 1993) (distinguishing rezonings that affect large numbers of people from those affecting smaller numbers and singling out the latter for additional required process).

87. 410 U.S. $113,152-53$ (1973).

88. 539 U.S. 558, 578-79 (2003).

89. 545 U.S. 469, 494 (2005) (O'Connor, J., dissenting).

90. Again, I make no presumption concerning the public norms that actually do the measuring of such laws. Rex finds no failure in his changing and harsh whims, as the absence of any consideration of the preferences of others is not a defect of laws within his system. 
On the public side, let us assume for a moment a basically utilitarian regime that is publicly concerned with aggregating preferences in some way deemed to be distributively fair over time. When lawmakers exhibit manifest distributive unfairness, the distributive advantage of public lawmaking is apparently absent, and with it the very justification for public, rather than private, power. Public laws are misplaced when they represent private redistributive efforts rather than public ones. We instead should resort to private law, with its requirement of consent.

In his concurrence in Kelo $v$. City of New London, Justice Kennedy highlighted this potential danger and noted that some government takings might be attended by facts so suggestive of impermissible private purposes that courts should engage in heightened scrutiny. ${ }^{91}$ Redistribution for private purposes should be conducted privately, adopted under the procedures for, and restrictions on, making private law (typically including consent of all those whose resources would be substantially reallocated). In our system, preventing majorities from running roughshod over minorities, meaning protecting against majoritarian governance that utterly lacks true, distributive advantage, is the backbone of all the substantive Constitutional rights, whether explicit or a task of the Due Process clause. ${ }^{92}$

On the private side, we are concerned with situations in which the lawmaking is plainly indicative of a failure to have private calculation advantage or of a serious, uncontrolled distributive disadvantage. These problems are solved doctrinally in the first instance by requiring voluntarism, so that generally, no one is coerced by private law who did not agree to be. But whether there was a truly voluntary agreement is sometimes difficult to say.

Unconscionability is the doctrine that scrutinizes private lawmaking for too dramatic a failure of private calculation. This doctrine has procedural and substantive prongs. ${ }^{93}$ Substantively, we are trying to see whether a contract was such a bad deal that no one

91. Kelo, 545 U.S. at 493 (Kennedy, J., concurring) ("There may be private transfers in which the risk of undetected impermissible favoritism of private parties is so acute that a presumption (rebuttable or otherwise) of invalidity is warranted under the Public Use Clause."). Justice Kennedy concluded that the mere fact that private parties ultimately receive benefits, even direct benefits, from a taking is not enough to trigger such heightened scrutiny. Id.

92. United States v. Carolene Prods. Co., 304 U.S. 144, 153 n.4 (1938); see also ELY, supra note 49, at 181 (suggesting that the judiciary "can appropriately concern itself only with questions of participation, and not with the substantive merits of the political choice under attack").

93. See Arthur Allen Leff, Unconscionability and the Code-The Emperor's New Clause, 115 U. PA. L. REV. 485, 487 (1967). 
could truly have agreed to it. ${ }^{94}$ When there is a manifest, privatecalculation failure, there is, in a sense, no true agreement..$^{95}$ Courts are generally reluctant to assert such a thing, as, after all, the parties did in fact agree to the contract, at least formally. Thus, courts often require a finding of some amount of what they call "procedural unconscionability," the act of lawmaking itself that the parties did not voluntarily enter the arrangement. ${ }^{97}$ It is only together that the promisor and promisee have a distributive advantage and private calculation advantage between them. If one made the law for both, without consent, that law would obviously lack these advantages. Unconscionability aims to spot such situations lurking behind apparent consent. ${ }^{98}$

Consider the obvious example of slavery laws. Public slavery laws fail the basic test of public lawmaking capacity because their very substance is indicative of an extreme failure in distributive competency. A legislature that orders the enslavement of some is plainly not taking into account the enslaved group's interests. A private contract to enter into slavery is likewise problematic. It is indicative of a failure of the advantages that justify resort to Contract in the first place, namely private calculation advantage. Where these advantages are so manifestly lacking, the Constitutional Law of Contract, Tort, or Criminal Law will be used to invalidate a law.

The above is only a sketch of the model's utility in uncovering inherent similarities and necessary differences between particular kinds of public and private Constitutional Law. The institutional perspective reveals that many aspects of the particular secondary

94. For a contrary view, see Seana Valentine Shiffrin, Paternalism, Unconscionability Doctrine, and Accommodation, 29 PHIL \& PUB. AFF. 205, 235 (2000) (asserting that unconscionability is grounded not in paternalism but in the state's obligation "not to assist grossly unfair treatment" even where there is true consent). Shiffrin's view would find unconscionability in areas where the parties are at a severe public calculation advantage. This view carries with it the argument that, at least in some areas, the public should have substantive norms that are unconnected to the satisfaction of private preferences, even when there are no private distributive consequences.

95. Private calculation failure is the most common justification for the doctrine. See Horacio Spector, A Contractarian Approach to Unconscionability, 81 CHI.-KENT L. REV. 95, 97-98 (2006) (though disagreeing, acknowledging that the doctrine is most commonly supported as an instance of justifiable paternalism).

96. Michael J. Herbert, Unconscionability Under Article 2A, 21 U. TOL. L. REV. 715, 723 (1990) ("In practice, however, it has generally been true that courts are reluctant to find a contract or a contract clause unconscionable ... unless there are at least some elements of both procedural and substantive unconscionability.").

97. Procedural unconscionability is thus an analogue of procedural due process to the (weak) extent it applies to lawmaking. Much of our procedural due process law, however, is aimed at regulating the procedure of adjudication. That is, it is part of the Procedure metalaw in this taxonomy.

98. See generally Philip Bridwell, The Philosophical Dimensions of the Doctrine of Unconscionability, 70 U. CHI. L. REV. 1513 (2003). 
rules of public and private lawmaking are consequences of two general principles. Obviously, much more work is possible here. Understanding substantive constraints as problems of institutional competencies opens a new window into the analysis of our own contract and constitutional law.

\section{B. Tort and Crime: The Principles Applied to Procedure}

Just as legal systems maintain secondary rules to govern lawmakers, they maintain secondary rules to govern the prosecution of claims that the laws have been broken. In the model, I have labeled this body of meta-law Procedure. Procedure governs the choice between public and private prosecution and the methods of and limitations on bringing of causes of action.

In this section, I will restrict attention to what Procedure should prescribe for the enforcement of publicly made law, which can either be Tort or Criminal Law depending on whether prosecution is initiated privately or publicly, respectively. Applying the basic principles and using the institutional calculus will lead to conclusions concerning which sorts of public laws are appropriate for each category.

Historical-substantive analysis of the crime/tort boundary is fraught with confusion. "Many people . . . have tried to answer the question, 'What is the essential difference between tort law and criminal law?' One important lesson of historical studies . . . is that the question has no answer." 99 But the difference between Tort and Criminal Law is more or less sharp, depending on our choice among the many valid definitions we could affix to these terms. What I call Criminal Law is the set of all publicly created duties that are enforced publicly rather than privately. To be more specific, by "enforced publicly," I mean that the public decides whether it will adjudicate an alleged breach of a publicly created duty. ${ }^{100}$ Focusing

99. David Friedman, Beyond the Tort/Crime Distinction, 76 B.U. L. REV. 103, 108 (1996).

100. To simplify the present analysis, I assume here that the power to force adjudication carries with it the obligation to fund and carry out prosecution. It is of course a theoretical possibility that a system can split these responsibilities. There are reasons, based in the atomic advantages, to believe that control will rarely be truly split. In the privately solicitous societies captured by this Part's assumptions, it would be anomalous for a public to force a private citizen to spend money and effort prosecuting against the individual's will. It would be similarly problematic if any individual could force government prosecution. Societies that permit the private invocation of public prosecution resources must ultimately have methods to control the fiscal impact, whether the ability to refuse to prosecute altogether or procedural means that can quickly and efficiently weed out frivolous claims. In either of the above cases, one would expect the entity charged with prosecuting often to have the power to decline, i.e., the power to decide whether to be burdened with prosecution. But I will leave this potential complication for another day, and assume for purposes of this Article that the two powers/obligations are identical. 
on institutional control over a specific question provides a relatively clear delineation. ${ }^{101}$

In this section, I begin by surveying several other methods of segregating Crime and Tort that have appeared in the literature, all focused on substantive methods of classification. I then analyze this boundary using the basic principles and the public/private institutional calculus, noting the fit and lack thereof with existing methods. Finally, I turn to the recent case of Robertson $v$. United States ex rel. Watson, ${ }^{102}$ in which the Supreme Court asked, but ultimately refused to decide, whether private parties could constitutionally bring criminal contempt actions. ${ }^{103}$ The model provides a helpful lens through which to study this question.

\section{Some Existing Approaches to the Tort/Crime Problem}

Even today the literature has not settled on what exactly is a tort and what is a crime. ${ }^{104}$ It has been suggested that the difference might center on whether the breach of the duty should be attended with moral stigma, whether the breach of the duty should be seen as undesirable always or only if causing an uncompensated harm, or whether the remedy seeks to correct a distributive imbalance by transferring wealth or to punish by making the defendant poorer. ${ }^{105}$

Confusion as to what distinguishes "torts" from "crimes" in our legal heritage is ancient. Blackstone wrote that "the king, in whom centers the majesty of the whole community, is supposed by the law to be the person injured by every infraction of the public right belonging to that community, and is therefore in all cases the proper prosecutor for every public offence."106 The assertions implicit in that

101. Note that the Criminal Law category in the model includes administrative actions against individuals and other cases that might normally be called "civil," owing to the type of remedy sought, the amount of stigma intended, and possibly the procedures desired. These other notions of what separates civil and criminal are discussed below.

102. Robertson v. United States ex rel. Watson, 130 S. Ct. 2184, 2185 (2010).

103. Id. at $2185,2190$.

104. See generally Kenneth S. Abraham, What is a Tort Claim? An Interpretation of Contemporary Tort Reform, 51 MD. L. REV. 172, 172 (1992) ("On their first day of law school, students falter until, eventually, it emerges that a tort is a civil wrong not arising out of contract. This almost completely circular definition is not enlightening ....").

105. See Friedman, supra note 99, at 108-09. Friedman argues that none of these three are essential and that there are or have been causes of action accompanying each combination of choices. Id.

106. 4 WILLIAM BLACKSTONE, COMMENTARIES *2. Blackstone elaborated:

The distinction of public wrongs from private, of crimes and misdemeanors from civil injuries, seems principally to consist in this: that private wrongs or civil injuries are an infringement or privation of the civil rights which belong to individuals, considered merely as individuals: public wrongs, or crimes and misdemeanors, are a breach 
formulation are (a) that some law violations harm the public at large and (b) that in these cases the public is the proper prosecutor. Thus, taking an approach opposite of mine, Blackstone set up Crime as a category defined by whether the infraction causes public, rather than private, harm. ${ }^{107}$ From this, we can deduce, supposedly, that the prosecution of crimes ought to be public.

In fact, as David Seipp has described in an excellent historical analysis, there was no distinct boundary between tort and crime in medieval England. ${ }^{108}$ One could choose to sue in "crime" or in "tort.."109 Suing in crime, through a cause of action called an "appeal of felony," made available vengeful remedies that could not be pursued in tort. ${ }^{110}$

Blackstone described the "appeal" as an enforcement of criminal law "merely at the suit of the [private] subject."111 More specifically, it was "an accusation by a private subject against another, for some heinous crime; demanding punishment on account of the particular injury suffered, rather than for the offence against the public."112 This action was not merely a companion civil action to a public criminal prosecution. A verdict from an appeal was binding on the Crown, precluding prosecution after acquittal. ${ }^{113}$ And on conviction the defendant would "suffer the same judgment, as if he had been convicted by [public prosecution] . ..."114

and violation of the public rights and duties, due to the whole community, considered as a community, in its social aggregate capacity.

Id. at ${ }^{*} 5$.

107. This approach to understanding the Tort/Crime divide is quite common and, as we shall see, natural. Randy Barnett has written about this kind of public/private distinction but in a more nuanced fashion, appreciating that some actions are "criminal" because of their harmful private effects, more so than attenuated public harms that flow secondarily from the private victim's loss. See Randy E. Barnett, Foreword: Four Senses of the Public Law-Private Law Distinction, 9 HARV. J.L. \& PUB. POL'Y 267, 268-69 (1986).

108. David J. Seipp, The Distinction Between Crime and Tort in the Early Common Law, 76 B.U. L. REV. 59, 59-60 (1996).

109. Id. at 59 .

110. See id. at 61-68.

111. BLACKSTONE, supra note 106 , at $* 312$.

112. Id.

113. Id. at * 315 . Interestingly, private prosecution by appeal could be had after acquittal or plea arising from public prosecution. Id.

114. Id. at ${ }^{\star} 316$. This included execution at one time:

[A]ll the relations of [a murder victim] should drag the appellee to the place of execution; a custom founded upon that savage spirit of family resentment, which prevailed universally through Europe, after the irruption of the northern nations, and is peculiarly attended to in their several codes of law; and which prevails even now among the wild and untutored inhabitants of America ....

Id. (footnote omitted). 
According to Seipp, the essence of the crime/tort distinction in (at least much of) medieval English history rested on the choice of the victim to seek vengeance, through appeal, or compensation, through writ of trespass. ${ }^{115}$ "[Victims] could either put their wrongdoers to death and collect nothing, or collect money for themselves and leave their wrongdoers alive with the rest of their wealth intact."116 In fact, private prosecution of crimes was very much the norm in eighteenth-century England, even though the actions bore the name of the Crown. ${ }^{117}$

David Friedman and others have asked, quite sensibly, why anyone would undertake the great expense of providing what amounts to a public good, the pursuit of non-compensatory, uncapturable public benefits, or at least a private good with significant public spillover benefits. ${ }^{118}$ There are a number of possible answers, including the potential for private prosecutors to extract large, private settlements using the threat of harsh, criminal remedies. ${ }^{119}$ But the expense of investigation and prosecution drove many individuals of average means to form prosecuting syndicates. As Friedman describes:

A group of potential victims, usually residents of the same town, would each contribute a few pounds to a common fund that they would use to pay the cost of prosecuting a felony committed against any of them. The members of the association would publish their names in the local newspaper, in part, presumably, for the benefit of local criminals. Thousands of such associations were created in England in the eighteenth and early nineteenth centuries. ${ }^{120}$

We therefore have an instance of a collection of privately enforceable, publicly beneficial laws around which at least some markets created collective prosecution solutions. The move toward private collectivism, by which I mean only that individuals within a collective formed a sub-collective to meet their needs, should prompt us to ask whether a private prosecution model makes sense for such laws. An analysis of the atomic advantages suggests that such

115. See Seipp, supra note 108 , at 84 .

116. Id.

117. See Friedman, supra note 99, at 103 ("[A] private party, usually the victim, initiated the action, located witnesses, arranged for them to appear in court, and fulfilled almost all of the functions that we associate with a public prosecutor.").

118. Id. at 103-05.

119. Friedman notes: "In both eras there were legal rules designed to prevent private prosecutors from dropping their charges in exchange for payment, but in both there is reason to believe that the courts did not always enforce those rules." Id. at 105 (footnote omitted).

120. Id. at 104-05 (footnotes omitted). 
syndicates were attempts to solve predictable resource and distributive problems faced by individual, private prosecutors. ${ }^{121}$

One might also attempt to divide Crime from Tort based on the kinds of remedies available or the measure of stigma imposed. Though some remedies, imprisonment and corporeal punishments for example, seem distinctly criminal and also symbolic of an effort to impose moral condemnation, other remedies under our criminal law, such as fines, do not appear all that different from the kinds of coercion ordered in a Tort case. ${ }^{122}$

\section{Tort and Crime in the Model}

We can more fruitfully explore a legal system by reversing the analysis: which institution, private individuals or the public, should bring adjudications to achieve our various legal goals? That is the question posed by this dimension of the model, whether the decision to spend resources adjudicating a law violation is privately or publicly controlled. ${ }^{123}$ Like other public/private distinctions, we should expect that the answer will be composed of the atomic arguments, the particular weight and arrangement of which will depend on more basic societal norms.

The two trans-substantive principles provide a starting point. The first principle demands, ex ante, that our private and public prosecutors be defined and procedurally constrained to provide likely institutional competency. The second principle conditions validity of prosecution on output that is not manifestly indicative, ex post, of

121. I leave for another day the question whether such problems are best achieved with collectivizing market innovations or with socialized prosecution of crime.

122. It seems to me difficult to divide criminal sanctions from administrative sanctions. In our own criminal law, constitutional regulation and legal form do in fact vary with the gravity of the punishment. But even this sort of spectrum is not without controversy. Whether two months' imprisonment is a "lighter" punishment than a $\$ 10,000$ fine is quite obviously a matter of circumstance-bound opinion.

123. This is not at all a novel way of looking at the distinction. Indeed, it was the view of the Romans. See James Lindgren, Why the Ancients May Not Have Needed a System of Criminal Law, 76 B.U. L. REV. 29, 38-39 (1996); see also JUSTINIAN's INSTITUTES 8 (Peter Birks \& Grant McLeod trans., 1987) (“[C]rimes are wrongs which society pursues, taking action through some representative, sometimes an official, sometimes any member of the public; civil wrongs are those for which the victim must bring his own action, if he can and will."). The further question of what kinds of laws, exactly, should be privately prosecuted and which publicly prosecuted depends, as I argue, on the chemistry of the atomic advantages. Lindgren uses the criterion that others have used to define Criminal Law as a reason to resort to Criminal Law (i.e. resorting to public prosecution): the presence of a "public" wrong. Lindgren, supra, at 40 ("[T]he public character of the offense is the paramount characteristic, wrongdoing or blameworthiness being relegated to a rationale or a side constraint. In general (though not in every instance), crimes are public wrongs, while torts are private wrongs."). 
institutional incompetence. We can again presume that private prosecution is preferable, while public prosecution must be justified.

\section{(a) The Trans-substantive Principles in Procedure}

Beginning with the first principle, it is helpful to imagine, with respect to the kinds of problems we think law is needed to address, what we want the law to do. That is, assuming a particular public law, does Procedure demand it be prosecuted publicly or privately, or does Procedure place the law in a zone of twilight in which either might prosecute? Is there a concept like consent that can be used to identify broad swaths of publicly-made law amendable to private control? The answer is yes, and the solution lies in observing the symmetry between the lawmaking and prosecution inquiries.

The reason consent to make law among private parties satisfies the first principle is that a consenting group has generally internalized all the costs, conceived broadly, of its actions, and concluded that the law's benefit is worth those costs. This is the key to identifying first-principle-compliant Procedural rules. When a private party sufficiently internalizes the costs and benefits of prosecution and is fully able to balance them against the law's benefit, he or she will be an atomically advantaged prosecutor. The questions then, to determine whether the first principle is satisfied, are whether private prosecution of a law will provide benefits that can be internalized and whether there is sufficient, if not complete, internalization of the costs of adjudication.

Interestingly, the application of the first principle reveals a similar disparity across the public and private Procedural dimension as it did across the Constitutional dimension. Namely, determining the ex ante competency of a private party is a fact-bound inquiry. It is, though called by different names, a question of standing-whether this private party is well-suited to decide whether adjudication is worth its costs. This requires us to decide whether the private party would be entitled to benefits if victorious and is within the zone of interests of the law. Only then would the private party internalize the important elements of the social decision whether prosecution is warranted. At that point, Procedure still demands that the prosecution be conducted in accordance with rules meant to conserve atomic competency.

In contrast, public prosecutors are identified and governed almost entirely by rule-based structural provisions. The provisions themselves, as an ex ante matter, satisfy us that whoever is put in the position of public prosecutor will likely be atomically competent. If it were otherwise, after all, we would change them. The question of what these rules should be is an interesting and specific application 
of the institutional calculus and is a twin to the sort of analysis Vermeule undertakes with respect to the Constitutional Law of congressional procedure. ${ }^{124}$

The second principle, in contrast, demands rules of Procedure to analyze prosecutorial output for manifest failing, despite the ex ante appropriateness of the prosecuting institution. Prosecution that turns out to be distributively flawed, for example, or to have been brought for a reason other than the public purpose for which the cause of action exists is subject to sanction, through procedural rules, auxiliary torts, or even criminal law. ${ }^{125}$

\section{(b) Application of the Principles}

I will briefly consider two different kinds of legal goals and consider what a generic but welfare-driven collective might make of the prosecution question as an ex ante, meaning first principle, matter. In both of these, the basic problems are (a) that private parties making unilateral prosecution decisions are at a distributive disadvantage, meaning they are not likely to consider fully the impact of the adjudication on others, and (b) that bringing a law violation to a successful adjudication can be expensive, such that the public usually, but not always, has significant resource advantages.

First, consider purely compensatory law. Imagine that a legal violation has occurred resulting in injury to some victim. The law in question has no other goal apart from making the victim whole. The question that must be answered is whether adjudication of this violation is worth its costs. Is the victim or the public in a better position to come closest to a socially optimal answer?

Where the victim can recover, at most, an amount roughly tied to his or her loss, we can expect victims, again roughly, to pursue adjudication when the injury was bad enough, and thus expected compensation high enough, to cover his or her own expected litigation costs. Though the victim will not internalize all of the litigation costs,

124. See supra notes 77-81 and accompanying text.

125. Public prosecutors are rarely disciplined for their misconduct or alleged misconduct, but private malicious prosecutions have often been brought. See Kalina v. Fletcher, 522 U.S. 118, 123-27, 124 n.11 (1997) (restating that prior Supreme Court decisions had "granted a broader immunity to public prosecutors than had been available in malicious prosecution actions against private persons who brought prosecutions at early common law"); see also Margaret Z. Johns, Reconsidering Absolute Prosecutorial Immunity, 2005 B.Y.U. L. REV. 53, 53 (2005) (" 'TT]he safeguards built into the judicial system tend to reduce the need for private damages actions as a means of controlling unconstitutional conduct.'" (quoting Burns v. Reed, 500 U.S. 478, 492 (1990))). The Supreme Court has suggested this may also be based on "firmly established common-law rules providing absolute immunity for judges and jurors" but not for purely private actors. Kalina, 522 U.S. at 124 n. 11 . 
and is thus at a distributive disadvantage, there is a rough proportionality at work that can be attuned to prevent too much useless adjudication. ${ }^{126}$ The uncertainty of the result, the amount in controversy, and the expense of litigation all work in tandem to yield a probabilistic calculus that could be calibrated to capture reasonably well the analysis that would be undertaken by a benevolent, omniscient dictator who in his or her heart would really know whether the adjudication was worthwhile.

Although the private prosecutor is undeniably at a distributive disadvantage, so long as he or she is made to internalize costs in decent proportion to those he or she is imposing on others, that disadvantage is controlled just enough that we can say that the private calculation benefits of private prosecution ought to be allowed to rule the day. ${ }^{127}$ Thus, we would expect to find Tort where the private prosecutor's distributive disadvantage is reasonably controlled, often by burdening him or her with proportionally significant litigation expense and secondary rules against malicious prosecution.

This analysis, however, leaves out another source of overall private disadvantage: resource disadvantage. But if the expected return from a lawsuit is reasonable, the market should provide the victim with access to the capital needed to sue. Indeed, contingency fee arrangements show how the market can provide the capital necessary for suits with reasonable, potential returns. The capital providers are now agents that perform the risk calculus described above to decide whether to prosecute. ${ }^{128}$ And the public may actually have to expend more resources to be as well positioned as the victim to put on a case, finding itself at a resource disadvantage.

Is there, then, a place for Crime among purely compensatory laws? Put differently, are there compensatory laws as to which the

126. I mean, here, adjudication that is not worth its costs, owing perhaps to its small chance of success or limited potential compensation.

127. I leave aside the possibility of schadenfreude, where the individual actually gains utility from imposing costs on another. There is probably no practical way of eliminating these vengeful passions from the legal landscape, but second-principle-derived court sanctions and malicious prosecution torts are efforts to control them, trying to maintain just enough cost internalization to align the private, selfish prosecution decision with the socially optimal one. The first principle suggests that either private prosecution be disallowed entirely or that the secondary rules punishing wrongful prosecution have special force in those areas in which schadenfreude is particularly likely. Examples might include dissolution actions and, especially, custody disputes, where the adjudicator may need to play a more inquisitorial role.

128. See, e.g., Lester Brickman, The Market for Contingent Fee-Financed Tort Litigation: Is It Price Competitive?, 25 CARDOzo L. REV. 65, 82 (2003) ("[C]ontingency fee lawyers assemble portfolios of cases, carefully screening claims and selecting only those which they expect to generate returns at least equal to their opportunity costs.") (footnotes omitted). Even after choosing to prosecute, lawyers increase or decrease capital allocation as a case's prospects change. $I d$. 
first principle finds private prosecutors to be atomically wanting but where public prosecutors are not? The model and the first principle encourage us to look for examples atom by atom. For compensatory laws, where there is good reason to think that private prosecution will only occur when seeking that compensation is worthwhile, a lack of resources might be a key barrier to private prosecution.

Mitchell Polinsky and Steven Shavell have pointed to several reasons why the resource disadvantage may be unusually high for some violations of such laws. ${ }^{129}$ First, where prosecution will be very expensive, as in cases in which the identity of the perpetrator is unknown and thus pre-adjudication investigatory costs are incurred (and often hard to estimate), capital will obviously be harder to raise. The more uncertain the investigatory project, the truer this is, even if there is social conviction that compensation ought to occur and that it is worth spending a great deal to achieve it.

Second, at least some types of investigatory capacities may be natural monopolies, and so it is unrealistic to expect the private market to provide them. Polinsky and Shavell cite fingerprint databases as a possible example. ${ }^{130}$ The collective as a whole has a tremendous resource advantage in establishing and maintaining large, expensive, universal, coordinated systems. Not only might it have a capital advantage, but the public may also have abilities unavailable to private parties to coerce cooperation and protect its monopoly status.

Finally, private parties may find themselves at a resource disadvantage relative to the public because of the public's access to forceful means, and presumably therefore much cheaper means, of gathering information. "[F]orce may be needed to gather information, capture violators, and prevent reprisal, yet the state frequently, if not usually, will not want to permit private parties to use force."131

What of laws that are intended to do things other than compensate? To begin, we should note that there are a number of non-compensatory goals that nonetheless can be assimilated to compensation for our purposes. Any public goal that consists solely in

129. A. Mitchell Polinsky \& Steven Shavell, The Economic Theory of Public Enforcement of Law, 38 J. ECON. LITERATURE 45, 46 (2000).

130. Id. I describe this as a resource disadvantage of the victim, because the victim does not have access to the resources necessary to effect a decision to prosecute. The reason the market does not provide the resources is that "private parties may find it hard to capture fully the benefits of developing expensive, but socially worthwhile, information systems." Id. In other words, private parties deciding whether to invest in such systems are at a distributive disadvantage compared to the public. Such parties disregard the external benefits to others, benefits they cannot capture, and may selfishly decide not to make a socially efficient investment.

131. Id. 
securing benefits for a private victim can be analyzed as above. The victim's private interests in effecting coercion for violations of such laws are the same as the public's. So long as the private prosecutor's distributive disadvantage is controlled and the resource disadvantage not too large, the first principle is satisfied and we would expect private individuals to make good prosecution decisions. ${ }^{132}$ For example, if the law's goal is to deter the defendant from again harming the victim, exemplary damages, though not exactly compensatory, have an essentially private purpose, and the benefits are amenable to complete capture by the victim. ${ }^{133}$

So too does the model capture a desire to provide a forum for a private party to vindicate dignitary interests. I consider a law to be compensatory when its benefits can be privately captured. These benefits, obviously, need not be purely monetary. A law intended to benefit a private party by granting a forum to gain public disapproval of another is such a law and could properly be a Tort law.

A problem arises, however, with laws that protect private individuals but which are also intended to confer non-compensatory, public benefits. Why have such goals? For one, compensation is not always possible or effective, as damage flowing from some types of

132. The categorization here is therefore consistent with, though more expansive than, the understanding of tort law supported by civil recourse theorists. See, e.g., Jason M. Solomon, Judging Plaintiffs, 60 VAND. L. REV. 1749, 1784-87 (2007) (contrasting the civil recourse theory of tort law with the corrective justice theory). With their focus primarily on " 'what the plaintiff is entitled to get' " rather than only on "what the defendant has done," civil recourse theorists understand tort law in a manner consistent with the first principle: focused on whether a private party is an appropriate prosecutor and if so granting the party the right, but not the obligation, to prosecute. Id. at 1786 (discussing and quoting Benjamin C. Zipursky, Civil Recourse, Not Corrective Justice, 91 GEO. L.J. 695, 733 (2003)). Because they are still interested in a substantive core that can be called "tort law," the civil recourse theorists look to define torts based on criteria concerning "wrongfulness," but at least wrongfulness relative to the private prosecutor. I am more agnostic about the substantive content of the category, leaving open that there can be reasons other than moral wrongfulness that render a private party atomically competent to prosecute the violation of a publicly made law. Obviously, this more expansive understanding of Tort Law could be only semantic: recourse theorists are concerned with "tort law," and I am concerned with "Tort Law," which includes other privately prosecuted public laws. I argue, but only defend partially here, that wrongfulness is a criterion that justifies inclusion in the broader category of Tort, but that the entire category, because of the institutional alignment, is governed by fairly consistent Constitutional and Procedural rules. That is, a group of laws' institutional similarity is generally more important than any historical-substantive similarity.

133. To the extent that we try to generalize this, say by calibrating the law to permit a private prosecutor to capture deterrence-based benefits enforcement bestows on others, for example by assessing punitive damages, we solve one distributive problem but create a calculation problem. When the deterrence benefits are solely monetary, and not in kind (for example, a grant of a restraining order protecting the victim-prosecutor) the private prosecutor no longer evaluates the worth of prosecution based on the benefits of deterrence as perceived by the victim, but rather only as monetized (imperfectly) by the public and made available to successful prosecutors. 
conduct "typically exceed[s] the injurer's wealth."134 Even if compensation might make a victim whole, the benefit of deterring similar injuries caused by this defendant or by others can justify additional prosecution effort than would be rationally undertaken to achieve compensation alone. And, of course, the expression of moral condemnation that prosecution can result in is not necessarily related to a desire to compensate any identifiable victim. We need not identify all such rationales now, as it is enough to observe that collectives do sometimes have non-compensatory goals for public laws. In these cases, private decisions not to prosecute may be distributively erroneous, because they will tend to ignore the public benefits of prosecution that cannot be captured by the private prosecutor.

Randy Barnett describes the problem:

The enforcement of legal regulation is a costly activity. If conduct that does not work a sufficiently great private harm-that is, conduct that does not sufficiently harm a particular individual or discrete group-is made the basis of a regulation of a "public law" type, then there will likely be no one with sufficient incentive to incur the costs of prosecution. As a result, once public law based on "public standards" is recognized, a need immediately arises to create "public" authorities to enforce these kinds of legal prohibitions. ${ }^{135}$

In terms of the public/private chemistry, the argument is that private individuals are at a potentially serious distributive disadvantage with respect to laws that provide benefits to others. They therefore discount those public benefits that cannot be privately captured. To see this concretely, consider the decision whether to seek redress, incurring investigatory and prosecution costs, against the thief of an inexpensive bicycle. The public's goal in redress goes beyond the single theft. It wants to prevent other thefts by this perpetrator, his or her descent into more serious criminality, and thefts by others who might be buoyed by the impunity with which people seem able to steal cheap bikes.

And so we see that understanding the distributive disadvantage of private prosecutors plays a critical role in designing a legal system's Crime/Tort divide. On the input side, where the expense of prosecution is partially externalized (through public funding of courts and the defendant's bearing his or her own litigation expense), private prosecution decisions will be skewed in favor of too much prosecution. Unless victims are made to bear the entire expense of

134. Antony W. Dnes \& Jonathan S. Seaton, An Exploration of the Tort-Criminal Boundary Using Manslaughter and Negligence Cases, 17 INT"L REV. L. \& ECON. 537, 537-38 (1997).

135. Barnett, supra note 107 , at 269. 
adjudication, which is only even conceivably justifiable as to laws that have the sole goal of compensating victims, this distributive disadvantage will encourage the overproduction of prosecution. The disadvantage must be controlled by calibrating victim expenses and putting in place second-principle, ex post remedies for "bad" prosecutions. ${ }^{136}$ On the output side, where the adjudication will provide public benefits that cannot be privately captured, prosecution will be underprovided. The distributive disadvantage will result in socially suboptimal investment in prosecution, meaning that it will too often not occur or, when it does occur, lack the level of effort that is socially justifiable in light of the adjudication's total benefits. ${ }^{137}$

While this dynamic almost always favors public prosecution, the first principle does suggest the appropriateness of qui tam actions, despite the fact that these actions do not compensate the private prosecutor for any personal loss. ${ }^{138}$ This would seem to suggest that qui tam plaintiffs lack the sort of standing that the first principle requires, and indeed the constitutionality and wisdom of qui tam has often been argued. But these actions are available on account of a distinct advantage private prosecutors have in certain types of law violations relative to public agents: resource advantage.

The False Claims Act permits private parties to sue for fraud on the government and claim a portion of the (multiple) damages

136. This is the role of the second principle, which measures decisional output for manifest institutional incompetency.

137. Some scholars have correctly emphasized that merely finding a potential failure of private incentives is not enough to justify a shift to public power. We are engaged here with a comparison of institutions, each with their own characteristic failings and advantages. As Randy Barnett writes:

[T] he creation of a monopolistic system of "public law" enforcement (in the second sense) generates serious social problems. "Public" institutions are given privileges and powers normally denied to "private" institutions-the right to confiscate resources forcibly ("taxation" and "condemnation"), for example-and this enhanced power increases the opportunity for corruption and the ability to abuse those who do not have such power.

Barnett, supra note 107, at 272. Calibration through Constitutional Law would be necessary to cure such problems. And so the analysis comes down to whether the failures of one institution or the other are easier to ameliorate.

David Friedman has suggested that the historical move away from private criminal prosecution might have a less benevolent explanation than avoiding private market failures. "The right to run courts and collect fines was a valuable property right," and a move away from private prosecution was a move toward enlarging the power and wealth of public authorities. Friedman, supra note 99, at 107. And so, perhaps, prosecution went public in order to realize the disadvantages of public control.

138. See, e.g., Evan Caminker, The Constitutionality of Qui Tam Actions, 99 YALE L.J. 341 (1989); Michael Holt \& Gregory Klass, Implied Certification under the False Claims Act, 41 PUB. CoNT. L.J. 1, 10 (2011). 
award. ${ }^{139}$ Detecting government fraud is thought to be most efficiently performed with the help of private parties. And so, the False Claims Act substitutes the normal first-principle standing requirement for one focused on assuring unusual resource advantage when the public lacks it. A qui tam "relator," i.e. private prosecutor, must have "direct and independent knowledge of the information on which the allegations are based and [have] voluntarily provided [such] information to the Government before filing an action . . .."140 Courts and Congress attempt to control the relators' distributive and calculation advantages with secondary rules and economic incentives.

Qui tam is a reminder that while the first principle is normally met through a sort of proxy like "standing," it demands atomic competency. That competency can be assured in a number of ways, not just by requiring standing.

\section{(c) Other Classifications as Derivative}

By considering the Crime/Tort divide in institutional terms and then analyzing the atomic advantages, we can derive the other, muddier distinctions that have been used to describe the two fields. These other distinctions can then be appreciated as consequences of the inherent differences in public and private capacities. For example, Blackstone's "violation[s] of the public rights" are infractions of laws that have publicly-oriented, non-compensatory goals. ${ }^{141}$ As he concluded, public prosecution is often desirable in such situations on account of the resulting distributive disadvantage of private prosecutors. ${ }^{142}$

Though he arrives at some of the same results, Blackstone's approach is less useful and provides less clarity. Mine is a model of the public and the private as institutions taking the fundamental actions I believe constitute a legal system: law definition, law enforcement, and remedy valuation. Focusing instead on the public or private character of the laws themselves obscures the relevance of institutional capacity in selecting public or private prosecution. ${ }^{143}$ Second, and arguably as a consequence of focusing on a public/private facet other than institutional control, Blackstone's approach turns out to be horribly messy. Whether a law protects public or private interests is a question that quite obviously invites hybrid answers. Some laws do both and to different degrees, and much will be in the

139. Holt \& Klass, supra note 138 , at 9-12.

140. 31 U.S.C. $\$ 3730(\mathrm{e})(4)(\mathrm{A})$-(B) (2006).

141. BLACKSTONE, supra note 106 at 6-8.

142. Id.

143. For this reason, it would not serve my longer term purpose of establishing a basis for analyses of the many types of institutions within legal systems. 
eye of the beholder. Duncan Kennedy's critique would bite into such a distinction with gusto. ${ }^{144}$

Another critical difference between our tort and criminal law that has been observed is that "tort generally provides the same sanction (compensatory damages) regardless of the defendant's culpability, while criminal law provides a sanction (punishment) that is proportional to the defendant's culpability." 145 My model turns this question around, resulting in a more natural policy question: (1) If we have policy reasons to seek compensation, should we use public or private prosecutors; and (2) if we have policy reasons to seek sanctions proportional to culpability without regard to a victim's injury, should we use public or private prosecutors?

Asking the questions this way demonstrates the utility of the atomic arguments. If private compensation can be offered in a way that minimizes the inherent distributive disadvantage of private prosecutors, through upfront expense and auxiliary rules, then the superior private calculation advantages of victims may be enough to make them superior prosecutors. There will be cases, though, where society prefers compensation despite the fact that achieving it costs more than a victim himself or herself would be willing to pay. In some cases, the public's superior investigatory and adjudicatory resources can achieve prosecution at a cost that would be privately acceptable, if it is all the victim would have had to pay.

Where the public has reason to seek non-compensatory remedies, private prosecutors' distributive disadvantage must be dealt with. In cases in which the benefits of adjudication can be captured accurately, such as the value to a victim of a restraining order or a well-tuned incentive to private attorneys-general, perhaps private prosecution can work. Generally, though, the public is the institution of choice to pursue remedies that are meant to achieve benefits extending beyond the victim.

\section{(d) Historical-Substantive Misalignment}

A primary source of friction between our tort and our criminal law comes in the form of private pursuit of such non-compensatory

144. Blackstone acknowledged this ambiguity, writing that "[i]n all cases the crime includes an injury: every public offence is also a private wrong, and somewhat more: it affects the individual, and it likewise affects the community." BLACKSTONE, supra note 106 , at ${ }^{*} 5$. He went on to argue that Crime is found wherever there is injury to the public as a whole. $I d$. at ${ }^{*} 6-7$. There may also be private redress for the purely private injuries resulting from the same acts, but these are often, at least with respect to more serious crimes, ineffective as compensation. Id.; see also Barnett, supra note 107, at 268.

145. Kenneth W. Simons, Deontology, Negligence, Tort, and Crime, 76 B.U. L. REv. 273, 296-97 (1996). 
remedies, usually in the form of punitive damages. In the course of supporting punitive damages in tort law, Angela Harris has attacked the relevance of the public/private distinction. ${ }^{146}$ "As a descriptive matter, the proposition that tort law is 'private' and concerned only with compensation, whereas criminal law is 'public' and concerned only with punishment, is inaccurate."147

Of course, she is correct. But we gain finer-grained insight with a more exacting understanding of what aspects of Contract and Tort are private and public. Using the model, the question becomes whether and when punitive (non-compensatory, publicly regarding) damages make sense if prosecution is privately initiated. That is, when a law is aimed at public as well as private harms, should the legal system allow private prosecution, and how, in such cases, should it handle remedies for the public portion of the harm caused by violations? The answer to these questions will obviously involve examining what amount of damages should be available and whether these exemplary damages would be awarded to the private prosecutor or to some public institution. But one cannot truly escape the public/private distinction when thinking about punitive damages, which are, functionally, rewards for successful private litigation, the alternative to which would be public prosecution. We are thus faced with a problem of institutional choice.

The Supreme Court's recent jurisprudence on the constitutionality of punitive damages can be understood as an effort to restrict the permissible punitive goals subject to private prosecution to those remedies least likely to promote heavily disadvantaged prosecutions. Among the main holdings: a requirement that punitive damages be a reasonable, perhaps even single-digit, ${ }^{148}$ multiple of compensatory damages and a requirement that the punitives that are imposed be based on conduct toward the plaintiff, not non-parties. ${ }^{149}$

These requirements have in common an aim to tie the private prosecution reward closely to the wrongful harm to the victimprosecutor. That is, punitive damages must be engineered to steer

146. Angela P. Harris, Rereading Punitive Damages: Beyond the Public/Private Distinction, 40 ALA. L. REV. 1079, 1079-82 (1989).

147. Id. at 1082.

148. See State Farm Mut. Auto. Ins. Co. v. Campbell, 538 U.S. 408, 425 (2003). For an excellent summary of the Court's evolving punitive damages jurisprudence, see generally Catherine M. Sharkey, Federal Incursions and State Defiance: Punitive Damages in the Wake of Philip Morris v. Williams, 46 WILlaMETTE L. REV. 449, 451-57 (2010).

149. See Philip Morris v. Williams, 549 U.S. 346, 357 (2007). In fact, in some states, "punitive" damages are only permitted to the extent they are "compensatory." See, e.g., Miller v. Drouin, 438 A.2d 863, 864 (Conn. 1981) ("In this state even punitive damages are designed not to punish the defendant for his offense but rather to compensate the plaintiff for his injuries."). Where compensation is explicitly the goal, the advantages, in a wellcalibrated system, point toward private prosecution. 
close to the compensatory goals that the chemistry of advantages usually suggests is appropriate for private prosecution. Prosecution choices made by victims under such a reward paradigm will be better positioned distributively than when out of proportion damages are possible. In that latter case, the rough semblance of litigation costinternalization discussed, supra, is lost, and litigation will be overprovided. And when the private prosecutor has the opportunity to recover for harms done to others, the private calculation benefits of private litigation are lost.

I do not intend here to defend the Supreme Court's recent punitive damages jurisprudence. But I offer the above arguments as suggestions for how the small number of tools implicit in the model can be used to analyze the issue.

\section{Robertson v. United States ex rel. Watson}

The problem of a particular law's place in the prosecutorial dimension of the model arose recently in the United States Supreme Court. The question on which the Court took certiorari was whether "an action for criminal contempt in a congressionally created court may constitutionally be brought in the name and pursuant to the power of a private person, rather than in the name and pursuant to the power of the United States." 150 Is the old English practice of private prosecution to achieve "vengeful remedies" consistent with the U.S. Constitution? Though the Court dismissed the writ as improvidently granted, four justices, led by Justice Roberts, dissented and would have held that private parties cannot bring such actions. ${ }^{151}$

The contempt charge arose from a domestic violence case. After an assault committed by her boyfriend, Ms. Watson obtained a restraining order. The boyfriend, Mr. Robertson, violated the order. He thereafter reached a plea agreement with the government concerning the original assault. In exchange for the plea, the government agreed, among other things, not to pursue charges stemming from the violation of the restraining order. Without regard to the agreement, Ms. Watson, herself, "filed a motion to initiate criminal contempt proceedings against Robertson for violating the civil protective order." 152 The court conducted a bench trial and found Robertson guilty of criminal contempt, sentencing him to probation and nearly a year in prison and also ordering him to pay restitution to Watson. ${ }^{153}$

150. Robertson v. United States ex rel. Watson, 130 S. Ct. 2184, 2185 (2010).

151. Id.

152. Id.

153. Id. 
Robertson argued that the plea agreement with the government forbade it from pursuing charges based on the violation of the protective order, and since only the sovereign may prosecute criminal contempt, any adjudication of that charge would amount to a double jeopardy violation. ${ }^{154}$ As has been mentioned, the Supreme Court granted certiorari with the intention of examining the piece of that argument asserting that contempt may only be brought by the sovereign.

The dissenters' argument against private enforcement of criminal contempt came down to the following lines of attack. (1) The constitutional protections for criminal defendants are all written as limitations on governmental action, demonstrating an implicit intent by the Framers to restrict criminal prosecution to public authorities. (2) Where "private" prosecution has been and is permitted, it is understood that the private party is only an agent of the government and that the state is the real prosecutor. (3) Even if some contempt actions are civil, this one was criminal on account of the evident statutory intent to classify it as such and in light of the penalties attached to it.

The dissenters summarized:

A basic step in organizing a civilized society is to take that sword out of private hands and turn it over to an organized government, acting on behalf of all the people. Indeed, "[t]he . . . power a man has in the state of nature is the power to punish the crimes committed against that law. [But this] he gives up when he joins [a] ... political society, and incorporates into [a] commonwealth."155

The key word here is "sword." At a more abstract level than the doctrinal analysis that preceded it, Justice Roberts asserted that laws that punish, rather than compensate, are enforced under the power of and at the discretion of the sovereign.

Under my model, and without the constraint of attempting to fit this case into any ambiguous doctrinal line, we would proceed a little differently. First, the question whether private prosecution is permitted is the question whether "criminal contempt" is a Tort or Criminal cause of action. By contrast, the dissenters considered whether (1) the law at issue was "criminal" and, then, (2) whether private entities can enforce criminal laws. These are not separate questions in my model. But the analysis that goes into the first question should be, to the extent possible, used to answer directly whether private prosecution is justified.

154. Id. at 2186 .

155. Id. at 2190 (Roberts, J., dissenting) (quoting John Locke, Second Treatise of Civil Government, $\S 128)$. 
The dissenters bifurcate the legal conflict in this case, confronting two legal uncertainties. What is crime? And can private citizens prosecute crime? If crime is defined to be the category of actions that are prosecuted by the government, then the former question automatically answers the latter. But we are still left to ask: What kinds of actions should be restricted to government prosecution? This question comes closest to getting at the heart of what is intuitively difficult about Robertson.

Should private parties be prohibited from compelling adjudication of this kind? As has been discussed above, it makes sense to take control away from private parties when they are significantly disadvantaged but where the public is not. As argued above, under the first principle, non-compensatory, public goals are generally not suitably protected by private adjudication, the public/private atoms pointing at both over- and under-provision problems. And so most criminal matters, with punishments calculated to deter both the defendant and other potential criminals who would harm other victims, are not efficiently brought by private prosecutors. Robertson, however, is not such a case. ${ }^{156}$

Ensuring compliance with the protective order through punitive sanctions was clearly designed, in this case, to deter future harm to Ms. Watson, not to the public at large. Though the public benefits if people like Ms. Watson are able to feel safe, she is not as disadvantaged in pursuing punitive sanctions as private prosecutors in other criminal cases pursuing punishments tuned to procure nonprivate benefits. The enforcement of this law, unlike many other criminal laws and owing to the nature of a protective order in a domestic violence case, redounds almost entirely to her benefit. Thus, this judge-made law is compensatory, and so Ms. Watson's prosecution of it is consistent with the first principle. After all, she is probably as well positioned as the public to determine whether the benefits of prosecution are worth the costs of prosecution. Relative to public prosecutors, she is not distributively disadvantaged in valuing the preferences of other members of the public, meaning her prosecution decisions will not be distorted by discounting the preferences of other potential victims, unlike in most other criminal prosecutions. It is arguable that we need not worry that prosecution will be under-provided in such cases..$^{157}$

156. See supra note 133 and accompanying text.

157. Prosecution is under-provided, within my meaning here, if prosecutions do not occur that would be socially desirable, either because society values Ms. Watson's preferences, for example, or because it would advance other social goals. The point, here, is that Ms. Watson as prosecutor satisfies the first principle, and so we should be relatively confident that she will prosecute when prosecution is publicly desirable. 
Over-provision may not be a problem either. It is true that where the sword of justice may cause great injury to a convicted defendant and where the victim (or tormentor, as the case may be) is made happy by the defendant's suffering, an incentive to prosecute arises that serves no valid public purpose. But again, in Robertson, the remedy is attuned to avert harm to Ms. Watson. Her pursuit of the cause of action does no more than force the Court to determine whether a proportional remedy is warranted in light of the breach of an order intended to protect her, not the public generally, from harm. In other words, not only does she capture the benefits of prosecution, but those benefits are calculated to do no more than deter harm to her specifically. Her protection is the public purpose. This quasicompensatory purpose, full private capture with little public spillover, suggests that she will not be at a great distributive disadvantage to public prosecutors with respect to the defendant. Nor will she be at a public calculation or aggregative disadvantage, since her own safety is the object of the law.

Private prosecution, whether classified in the historicalsubstantive framework as civil or criminal, always carries with it some additional monitoring costs. This is so because of the strong private incentive to evade defendant-protecting prosecutorial practices compelled by Procedural and Constitutional rules, rules intended to ensure better accuracy in light of the gravity of the punishment. ${ }^{158}$ Being fair in litigation is a cost the distributively imperfect litigant will seek to avoid. But this is true also of public prosecutors, even if to a lesser extent. The second principle yields secondary rules that monitor the act of prosecution for manifest atomic failure, either controlling it through intervention by a judge or even throwing out the prosecution. It is possible that the Robertson case raises the danger that part of the benefit to private "criminal contempt" plaintiffs is schadenfreude, which is likely not a private preference that social norms would aggregate when calculating the public good. This is a danger in any prosecution, maybe more so in private prosecutions, and maybe more so still if the remedies impose liberty deprivations on the defendant. As discussed above, there is reason to think that this is less a problem here, but certainly the second principle would indicate a greater role for judicial monitoring because of the danger.

158. See John D. Bessler, The Public Interest and the Unconstitutionality of Private Prosecutors, 47 ARK. L. REV. 511, 562 (1994); see also New Jersey v. Imperiale, 773 F. Supp. 747, 753-54 (D.N.J. 1991) (noting that malicious prosecution actions are not sufficiently corrective, owing to the difficulty of meeting the standards of proof and the inherent difficulties of policing a variety of Due Process violations, including the withholding of Brady material). 
In sum, Robertson asked whether the enforcement of contempt orders focused on purely private protections, where punitive remedies could be imposed, is appropriate for a private victimprosecutor. We have seen that the first principle in many instances compels public prosecution where the law imposes punitive sanctions. Prosecutions for contempt of orders intended solely for the protection of the victim might, however, be an area where privately sought punishment is consistent with the first principle.

\section{Illuminating Law's Darker Corners}

The second type of implication I will highlight in this initial sketch is the illumination of seemingly ad hoc areas of our law as bearing structural significance. All laws have some place within the model's categories. The model gives us the ability to question this placement in light of the alternative institutional placements. It exposes options to legal system engineers and allows them to examine whether a law's placement among public and private institutions is sensible in light of the law's purposes.

An example of an under-theorized option within the institutional taxonomy is the category I call Parens Patriae. While Contract is by far the more important body of private law in our own system, the model yields a formally equal position for the enigmatic Parens Patriae category. ${ }^{159}$ This category represents those laws made by private parties but enforced by public authorities. Quite obviously, such laws present an opportunity for private parties to impose on the public the cost of pursuing their own objectives. And so we should expect this to be a somewhat sparse and perhaps even empty category. But it is not, in American law, a null set.

Parens patriae, in its traditional, legal usage, is the doctrine under which the state represents private individuals, traditionally children or the incapacitated, including the beneficiaries of charitable trusts. ${ }^{160}$ I use the phrase because it is suggestive of the type of suit in this box, a publicly prosecuted action to enforce privately made law. One important caveat: this category does not include so-called parens patriae litigation by states representing their citizens in

159. The rarity of laws in this category and the particular circumstances in which it is the most appropriate category suggest an analogy to Calabresi and Melamed's "fourth rule." See Calabresi \& Melamed, supra note 5, at 1116-17. That the model illuminates an array of options and the circumstances in which they are sensible is one of its chief virtues.

160. See, e.g., KERRY O'HALLORAN, MYLES MCGREgor-LoWNDES \& KaRLA W. SIMON, Charity LaW \& Social Policy: National and InTernational Perspectives on the FUNCTIONS OF THE LAW RELATING TO CHARITIES 120 (2008). 
federal antitrust cases. ${ }^{161}$ Such suits enforce the provisions of publicly enacted antitrust law. ${ }^{162}$ I use the term only for public suits to enforce privately created law.

The Contract/Parens Patriae choice, on the "privately created" side of the model, mirrors the Tort/Crime problem, on the "publicly created" side. Under what circumstances might a collective prefer public rather than private prosecution of privately created law, that is Parens Patriae rather than Contract? Applying the first principle, just as in the Tort/Crime distinction, we might opt for public enforcement when private parties would be at a distributive or resource disadvantage, where prosecution would be thereby underprovided or over-provided by private parties, and where public prosecution would be less defective.

The law of charitable trusts is just such an area, and it is perhaps the only area of American law that truly falls in the Parens Patriae box. When a settlor has made available funds for a significant class of individuals and for a charitable purpose, the law generally restricts representation of the beneficial interest to the state Attorney General. This is a longstanding rule that has been explicitly based on the state's duty to represent the public in parens patriae. ${ }^{163}$ The majority of states have codified this ancient rule and require the Attorney General to be the exclusive representative of the beneficiaries in charitable trust cases. ${ }^{164}$ Courts examining the policy

161. See, e.g., Alba CONTE \& HERBERT B. NEWBERG, 6 NEWBerg on Class ACtions $\S$ 18:55 (4th ed. 2002); Richard A. Posner, Address, Federalism and the Enforcement of Antitrust Laws by State Attorneys General, 2 GEO. J.L. \& PUB. POL'Y 5 (2004) (criticizing the states' use of parens patriae power in bringing antitrust actions).

162. Though this is not an illustration of what I call Parens Patriae, it is an illustration of public prosecution of public duties. As we saw in the last section, supra, the rationale for moving to public prosecution is similar:

[T] the three factors that normally determine whether a quasisovereign interest is sufficiently important to permit standing [to sue as parens patriae in antitrust] are (1) the size of the segment of the population that has been adversely affected, (2) the magnitude of the harm inflicted, and (3) the practical ability of those injured to obtain complete relief without intervention by the sovereign.

72 AM. JUR. 2D States, Territories, and Dependencies $\$ 91$ (2001) (citing P.R. ex rel. Quiros v. Alfred L. Snapp \& Sons, Inc., 632 F.2d 365 (4th Cir. 1980), aff'd, 458 U.S. 592 (1982)).

163. See, e.g., Trs. of Sailors' Snug Harbor v. Carmody, 144 N.Y.S. 24, 37 (N.Y. App. Div. 1913) ("From the earliest times the Attorney-General, in England and in other jurisdictions where trusts for charitable uses have been recognized, has been regarded as the representative of the uncertain beneficiaries of a charity.").

164. RESTATEMENT (SECOND) OF TRUSTS $\S 391$, cmt. a (1959); see also, e.g., CONN. GEN. STAT. $\S 3-125$ (2011). There are exceptions, including the permitting of suits by beneficiaries with "special interests." See, e.g., Holt v. Coll. of Osteopathic Physicians \& Surgeons, 61 Cal. 2d 750, 753 (1964) (discussing types of special interests that support the power to enforce a charitable trust). 
basis for this rule have concluded that placing exclusive enforcement power in public hands protects the limited charitable funds, and thus the settlor's intent, from depletion in litigation by various members of a large class of the public. ${ }^{165}$

Just as with criminal prosecution, resorting to the model chemistry helps us to see whether private parties or the public are better positioned to decide whether resources should be devoted to adjudication of an alleged law violation, here the terms of the trust. Like all private prosecutors, those wishing to attack the administration of charitable trusts are stereotypically subject to distorting resource or distributive disadvantages. With charitable trusts, the problem is unusually acute, justifying in at least the subconscious minds of lawmakers severe restrictions or prohibition on private enforcement.

The central difficulties are two-fold: the potential for over- and under-provision of private prosecution. First, the corpus of a trust is limited and the very purpose of the gift would be destroyed if too much of it is spent litigating its allocation. This sets up a classic tragedy of the commons, as an analysis of the atomic advantages demonstrates. Private parties are at a significant distributive disadvantage when deciding whether to litigate, as the litigation costs are not all borne by the litigant. Some costs are spread over all beneficiaries of the now-depleted corpus. If the potential award exceeds the private prosecution costs, the suit will go forward, even if the prosecution is not cost-justified in the aggregate. Prosecution may thus be over-provided. Though this is not superficially different from the distributive difficulty that arises in pure Contract law, the number of potential plaintiffs changes the equation. Though we, perhaps begrudgingly, accept distributively imperfect prosecution decisions in Contract, where the parties have accounted for this possibility and have means to discourage one another, charitable trusts present a different case. The sheer number of distributively imperfect, potential prosecutors is much more likely to lead to inefficient surplus depletion than in other kinds of contracts. ${ }^{166}$

Second, where a charitable trust provides relatively small gifts to a large class, there is a danger that prosecution will be underprovided, again owing to the distributive disadvantage of private litigants. Here again, the litigant will consider only the private benefits and costs of litigation, and an illegally administered trust will not offer significant enough reward to private plaintiffs to justify

165. See, e.g., Wier v. Howard Hughes Med. Inst., 407 A.2d 1051, 1057 (Del. Ch. 1979).

166. After all, charitable trusts are characterized by the generality of beneficiaries. From my perspective, though, this identifiable feature is what leads us to define the category and treat it differently by placing it in the Parens Patriae box. 
suit. This is precisely the problem we encountered in Crime/Tort, in which private prosecution to accomplish non-compensatory public goals would be under-provided. No aggrieved individual will be willing to prosecute even when the total benefits exceed the litigation's costs, because no individual will be able to capture all the benefits. ${ }^{167}$ While class actions could solve this problem (and we could think of class action plaintiff firms like the old English prosecution syndicates), they will run into the over-provision problem above.

\section{A Possible Third Dimension: An Aspect of an Aspect of the Cathedral}

One of the core insights of Calabresi and Melamed's "Cathedral" is that at the heart of the question of remedies lies a choice between public and private control of the terms of transaction in the postadjudication environment. ${ }^{168}$ The Cathedral's normative implications concerning property rules and liability rules derive from generic public/private capacity arguments applied to the question of remedies. To see why this is so, consider the basic distinction drawn by Calabresi and Melamed between these two ways of protecting entitlements.

Property rules grant to the winner private control over the entitlement after adjudication. The winner is entitled to prevent transfer to the loser unless an agreement acceptable to the winner is reached. Liability rules retain public power over the entitlement ex post by publicly setting the value that must be transferred to the winner in exchange for the entitlement. As Calabresi and Melamed explain:

An entitlement is protected by a property rule to the extent that someone who wishes to remove the entitlement from its holder must buy it from him in a voluntary transaction in which the value of the entitlement is agreed upon by the seller. It is the form of entitlement which gives rise to the least amount of state intervention: once the original entitlement is decided upon, the state does not try to decide its value. . . Property rules involve a collective decision as to who is to be given an initial entitlement but not as to the value of the entitlement. ${ }^{169}$

The property rule is a grant of private control to the winning litigant. That person or group has the power to dictate what shall become of the things or actions under dispute. Property rules devolve

167. This is precisely the reason Steven Shavell identifies for public enforcement, i.e. criminal enforcement, of public health code violations, even when there are injured victims. See generally Steven Shavell, Specific Performance Versus Damages for Breach of Contract: An Economic Analysis, 84 TEX. L. REV. 831 (2006).

168. Calabresi \& Melamed, supra note 5, at 1090.

169. Id. at 1092 (footnote omitted). 
the question of how the world should appear after collective intervention to the private parties to the dispute, but they entitle one of those parties, the victor, to hold out no matter how infuriating to the other. This typically means that the court grants an injunction to the victor, forcing the loser, who wishes to be free of the injunction, to meet the victor's terms in a post-adjudication settlement.

The liability rule, by contrast, displaces the private judgment of the victor for public judgment concerning the value of the disputed entitlement. If the loser "is willing to pay an objectively determined value" for an entitlement, he or she is privileged to destroy it, or, put less aggressively, to transfer it. ${ }^{170}$ The state, not the private winner, controls the value of the entitlement in the ex post, meaning postadjudication, negotiating environment. ${ }^{171}$ This typically means that the court calculates and imposes damages that might be lower than what the victor would have demanded of the loser.

Just as I have done in the lawmaking and enforcement dimensions of the model, Calabresi and Melamed shifted our understanding of remedies away from apparently ad hoc alternatives tied historically and substantively to particular causes of action. ${ }^{172}$ Instead, the Cathedral correctly apprehends the remedial decision as a choice primarily between discrete and logically arranged institutionally defined alternatives. ${ }^{173}$ With the larger understanding of law made possible by the taxonomy and institutional calculus, viewing remedies as choices between institutions is an obvious move.

170. Id.

171. See id. Calabresi and Melamed introduce a third kind of remedial rule: the inalienability rule. Id. But I do not understand the "inalienability rule" to be a separate, qualitative category. In my terms, the inalienability rule is a limiting case of the liability rule. Formally, the collective imposing an inalienability rule or a liability rule is taking for itself the power to set the terms of ex post entitlement transfer. Whereas Calabresi's and Melamed's liability rules encompass finite damage awards, inalienability rules are, again formally, a conditional award of infinite damages. To see this more clearly, consider that the higher the damages award, the less likely ex post transfer is to occur. At some point, the damages are so high that transfer is virtually certain not to occur. This level of damages represents a practical inalienability rule. An actual inalienability rule may simply be viewed as the setting of damages at an impractically high level. For example, in the iconic case of Boomer v. Atlantic Cement Co., 257 N.E.2d 870 (N.Y. 1970), the Court awarded permanent damages to neighbors of a polluting cement plant but allowed the plant to continue in operation. It did this by granting plaintiffs an injunction that would be dissolved upon the payment of court-determined damages sufficient to compensate for the pollution servitude that would be imposed on plaintiffs' land by the plant's continued operations. Id. at 875 . It is obvious that the higher these damages, the less likely the cement plant would be inclined to pay them. At some point, the damage award exceeds the value of the plant, and the plant will not "buy" the right to pollute. At this point, the liability rule is a practical inalienability rule. Voluntary transfer at some lower price is barred by a separate, publicly created prohibition on transfer that operates like any other publicly created duty.

172. Calabresi \& Melamed, supra note 5.

173. Id. 
Doing so renders some basic questions of remedies susceptible to the same tools, the atoms, as the other structural dimensions. One benefit of the general approach to legal systems I have advocated is that it makes transparent both the shift from substantive understandings to institutional understandings of legal systems and the analytical consequences that follow. This work is ultimately a generalization of this aspect of the Cathedral.

While many have elaborated on Calabresi's and Melamed's analysis, ${ }^{174}$ I focus here on recovering through the model only that part of their project that comprised an analysis of the choice between public and private control of the terms of the post-adjudication negotiation environment. Once the Cathedral shifted the focus from an unorganized constellation of remedies with various substantive goals to the distinction between the property rule and liability rule, that is to a choice between public and private control over an entitlement after adjudication, scholars and judges could analyze remedies in the language of institutional capacity, unleashing the power of the atomic arguments.

In their language, Calabresi and Melamed argue for liability rules when the cost of valuing the disputed entitlement is high, as may occur when one side to the dispute contains holdouts or freeloaders, but also simply as the result of the expense of coordinating large numbers of people. ${ }^{175}$ Furthermore, injunctions do no good to compensate the victim of an automobile accident. We cannot rely on the accident victim to tell us, ex post, what the injury was worth to him or her. ${ }^{176}$ While pre-accident contracts might supply such information, they would be impracticably expensive to enter. ${ }^{177}$

Collective valuation is justified on efficiency grounds, Calabresi and Melamed tell us, when it efficiently removes such problems. ${ }^{178}$

174. Id. Ian Ayres and Jack Balkin have explored the question of entitlement protection after the execution of a liability rule. Ian Ayres \& J.M. Balkin, Legal Entitlements as Auctions: Property Rules, Liability Rules, and Beyond, 106 YALE L.J. 703 (1996). That is, after the loser has paid damages, may he or she hold out on offers by the original holder to buy back the entitlement, or may the entitlement holder pay damages and force a re-transfer? I do not further explore here the question of higher order property or liability rules, other than to note that at each "level," the problem is to decide whether private or public control over the negotiating environment is desirable. See also IAN AYRES, OPTIONAL LAW: THE STRUCTURE OF LEGAL ENTITLEMENTS (2005) (describing property rules and liability rules in terms of option theory). Ayres's work points to a potentially more complex understanding of the public and private role in the ex post environment, but it does not alter the atomic role of each concept in informing remedial decisions. The translation I give of The Cathedral here is a beginning, not an end of this interesting dimension.

175. See Calabresi \& Melamed, supra note 5, at 1106.07.

176. See id. at 1108-09.

177. But note that, as a private market innovation, insurance could do this. Even though it currently operates in the shadow of expected liability-rule calculations.

178. Calabresi \& Melamed, supra note 5, at 1107. 
On the other hand, switching to a liability rule would be a mistake if, for example, a putative holdout is in fact disclosing his true valuation and not simply going after the largest chunk of the collective surplus he thinks he can get, risking derailing an otherwise Pareto-efficient transaction. ${ }^{179}$

In the institutional language of atoms, the choice between private and public control over the ex post bargaining situation comes down to an analysis of the public and private advantages applied to ex post bargaining. The essential design task facing legal system engineers is to identify easily demarcated categories of cases that will yield ex post environments where the usual advantages of either the public or private individuals are realized or are attenuated.

Translated into atomic language, Calabresi and Melamed have argued (a) for liability rules when private decisionmaking will involve distributive and resource disadvantages (holdouts and assembly problems) ${ }^{180}$ that have the effect of blocking efficient bargains (which they assume, in the absence of "other justice reasons," to be the choice of an institution with aggregative advantage), and (b) for property rules where the public is at a severe private calculation disadvantage (where it is much more difficult for the public properly to assess the private ex post valuations of the disputed entitlement). ${ }^{181}$ In other words, when do private individuals, together, fail to have the typical private calculation advantage or possess unusually high distributive disadvantage in the ex post negotiating environment? Such disabilities, along with the more stereotypical (even if slight) aggregative and public calculation disadvantages private individuals suffer, would justify a move to liability rules, public control, at least where the advantages of public control exist. ${ }^{182}$

Our contract law, despite its otherwise private character, for the most part eschews private control over remedies for precisely these reasons. Specific performance and the enforcement of liquidated

179. See id. at 1106-08.

180. For a more quantitative analysis, see Hylton, supra note 56 , at $148-50$.

181. See Calabresi \& Melamed, supra note 5, at 1102-05; Hylton, supra note 56 at 155 56 (explaining the importance of private calculation advantage in choosing between property and liability rules).

182. Where there could be clear advantages in favor of public control, ensuring that such advantages are actually obtained is an institutional design problem. That is, ensuring that the public actually has distributive and public calculation advantage is a design task focused on the means of choosing agents that are likely to possess these qualities over areas of their authority. For example, requiring judges to recuse in cases in which they have pecuniary interests is a rule of Constitutional Law meant to be conservative of prototypical public advantages. Other "legal technologies" help dampen the public's calculation, aggregative, and distributive defects. 
damages, property rule protections of contractual rights, are famously disfavored. ${ }^{183}$

Steven Shavell's economic analysis of contracting parties' rational choices of property rules (specific performance) or liability rules (expectation damages) in contract law highlights the critical role of the atomic public/private advantages. ${ }^{184}$ In contracts to produce, he argues, private parties take on enormous risk by agreeing to specific performance, if the cost to perform is sufficiently uncertain and wide in range. ${ }^{185}$ This creates the opportunity for the in-compliance counter-party to hold out for more than the value to him or her of the performance and may in fact lead to inefficient performance. ${ }^{186}$ Because of this, parties will themselves prefer expectation remedies, i.e. liability rules, to govern such contracts. ${ }^{187}$ The problem, in the language of the model, is that the private party's inherent distributive disadvantage becomes overwhelming in an ex post environment involving the division of large surpluses or losses. The private party empowered to control such an ex post environment is distributively disadvantaged, meaning that it fails to seek a jointly maximizing settlement. Knowing this in advance, parties contracting for types of performance that hold the potential for large divisions will generally opt for liability rules.

In contracts to transfer land, by contrast, the cost to perform is generally bounded by what someone would in fact pay for the property in the market, leading to less potential divergence between the cost of performance and the value to the transferee and thus less potential disruption from the transferee's inherent distributive disadvantage. And so, the private calculation disadvantages of liability rules (public control) become the more concerning source of error. ${ }^{188}$

Interestingly, the model helps us to see why and where we might want to depart from the production/transfer dichotomy. Since the

183. They are property rules, as each gives to the victor the right to insist on performance within the terms of the contract. Alan Schwartz has famously argued that specific performance should be more readily available. Alan Schwartz, The Case for Specific Performance, 89 YALE L.J. 271 (1979).

184. See Shavell, supra note 167 , at $833-34$.

185. Id. at 833 .

186. Indeed, the non-breaching party may hold out for a sizeable portion of the cost of performance, which, in production contracts, may be much larger than the value to the party of the breacher's performance.

187. Shavell, supra note 167 , at 841-43.

188. See id. at 851-52. Interestingly, there are identifiable situations, even in production contracts, in which potential private calculation errors are so large that property rules are indicated. See id. at $846 \mathrm{n} .48$ (giving an example where "the contract is to construct custom cabinets for a home in an area where there is no organized market for the kind of work involved and that the court can readily determine whether the job has been satisfactorily accomplished"). 
distinctive treatment of those areas is justified by the usual line-up of the atoms within production and transfer scenarios, departure is justified in subcategories where those stereotypical line-ups do not occur. For example, production contracts in which the value of the product is highly idiosyncratic and not subject to easy market valuation are contracts as to which an individual's private calculation advantage is quite high. At least in situations where the cost of performance is not obviously out of proportion to a conceivable private valuation, and thus the distributive disadvantage has a reasonably limited impact, we might opt for specific performance. A private party's high distributive disadvantage, at least where it is at least somewhat controlled, can be outweighed by that party's large private calculation advantage. ${ }^{189}$

This brief foray into the taxonomy's implications for a remedial dimension of legal systems demonstrates the value of a consciously institutional approach to legal classification. Once understood as a problem of institutional choice, we can take stock of the state, in a given class of cases, of the usual institutional comparators. Doing so, applying the generic atoms systematically (but again, not deterministically), we uncover what otherwise seem to be subjectspecific arguments. Understood as an institutional question, the remedial question is rendered susceptible to institutional arguments, and that fact makes the profound methods and problems of the Cathedral transparent.

\section{CONCLUSION}

What I have put forward in this Article is a beginning. Understanding legal system design as a multi-dimensional exercise in separating public and private control has a number of implications, uses, and mysteries. What follow are some additional questions to explore.

Efficient Structure. This Article provides a start at understanding a number of structural legal questions in terms of institutional advantages. Much more is possible. For example, choosing between private prosecutors and public agencies to enforce remedial laws is at the heart of a number of heavily contested issues. When are consumers best protected by private prosecutors in large class actions, and when are they better represented by public agencies? What are the proper subjects and limits of qui tam actions, where the

189. Shavell gives a nice example of such situations. See id. at $846 \mathrm{n} .48$ (describing a "contract ... to construct custom cabinets for a home in an area where there is no organized market for the kind of work involved and [where] the court can readily determine whether the job has been satisfactorily accomplished"). 
private prosecutor brings an action to remedy harms to the public, not himself? I have explored briefly actions that are properly placed in the Parens Patriae category, those brought to enforce private law on behalf of private parties, but where private prosecution is nonetheless structurally inferior to public prosecution. What "Filius Patriae" actions, those meant to remedy public harms resulting from public law violations where public prosecutors are nonetheless inferior to private prosecutors, should be included in Tort Law?

Comparative Law. A second line of inquiry prompted by the taxonomy is in comparative law. The taxonomy provides a method for characterizing a legal system, and, thus, it provides a way of comparing legal systems. Systems differ in how they populate the boxes of the taxonomy, and examining those differences could yield interesting insights into the fundamental distinctions between legal regimes.

Sub- and Super-Sovereigns, Pluralism. Third, nothing in this Article relied on the collective's being an officially recognized sovereign. In fact, the taxonomy can be used to study arbitrary collectives. All societies are individuals mapped onto a set of manifold and overlapping collectives. We are citizens of our nation, residents of our towns, members of the PTA, members of our families, etc. Our state is a member of our nation, which is a nation state within various international governing bodies, and so forth. The taxonomy developed here applies to all of these collectives. And so, every society is a complex of these taxonomic entities, overlapping and repeated at multiple scales: in short, pluralistic. Seeing a society as a mosaic and partially hierarchical mosaic of lawmaking collectives is an exciting way to understand pluralism. To give some idea, the Criminal Law of the local PTA might be enforced within the PTA but might also be reviewable under the Contract Law of the state in which the PTA is incorporated. So too, the operator of a virtual world may set up rules for online behavior enforceable in the operator's own Tort, Contract, or Criminal Law system. Should those judgments be reviewable, or other conduct within that collective be enforceable by the "supersovereign," the state or nation in which the operator and/or participants exist? The atomic public/private arguments may help understand these questions better.

Pedagogy. Just as understanding the difference between the substantive law of Contracts and the Constitutional Law of Contracts helps us understand the connections between Contracts and other substantive areas, so too might it help our students. At most U.S. law schools, the first-year curriculum consists of the following courses: two courses in the substance of publicly created duties (torts and criminal law), one in the Constitutional Law of privately created duties (contracts), one in polymorphic legal forms (property), one in 
procedure ${ }^{190}$ and, finally, one in a portion of the Constitutional Law of publicly created duties.

While scholars have long noticed and are increasingly appreciating the sui generis and interdisciplinary role of Property, ${ }_{191}$ little connection has been made between the constitutional law and contracts courses. And yet, they are in many ways as similar as the criminal law and torts courses. In each of these similar pairs, we ask the same questions and arrive at somewhat different answers. Most of this difference follows from not much more than the fact that one is public and the other private, as to source in the former case and as to prosecution in the latter, the atomic arguments at work to translate between fields.

But this understanding of what we teach also makes plainer what is left out of the first year study of fundamentals. First, most contracts courses do not cover the substantive law of Contracts. As remarked, supra, doing so is not possible in the same sense as is done with the substantive Tort law. Owing to the simple fact that substantive, private rulemaking is, well, private, the obligations so created are manifold and continuously variable. Thus, we do not teach the "law of private obligations relating to the agreement of $X$ and $Y$ regarding a particular shipment of chickens" but, instead, the meta-law, the Constitutional Law, governing the interpretation of contracts generally, including those contracts related to chicken commerce. These meta-laws govern the treatment by courts of privately made laws, dealing with such problems as incompletely specified contracts that leave out elements like price, a problem of the interpretation of private statutes, and contracts that are unconscionable. We teach the substantive law of contracts only through the series of examples primarily intended to illustrate the Constitutional Law of Contract.

Second, we do not often teach first year students much of the true Constitutional Law of Tort and Criminal Law. We focus instead on

190. Curiously, the Procedural Law of publicly enforced claims is often (perhaps universally) left to law schools' second and third years and is usually not even a required course. Though some might argue its fundamental difference, I would submit that teaching civil procedure goes a long way toward conveying what is needed to understand our criminal procedure. Though it is easy to emphasize the distinctions, in broad form the manner of bringing a criminal action and a civil action are nearly isomorphic. What is distinct merits further study in the form of a course in criminal adjudication, but one can explain a lot about that topic by noting how our civil procedure must be modified to deal with the shift in antagonist from a private actor to a public one. In other words, the same old arguments that explain the different form taken by "legal objects" when in the tort world rather than the contract world also explain the changed nature of procedural forms when in a criminal rather than civil setting.

191. See, e.g., Thomas C. Grey, The Disintegration of Property, in Nomos XXII: PROPERTY 69-73 (J. Rolan Pennock \& John W. Chapman eds., 1980). 
the structure of the federal government and the rights that further its and its subordinates' powers. Other aspects of Constitutional Law, chief among them the implied Constitutional Law under which our courts operate when they evolve the common law or interpret statutes is taught only obliquely.

\begin{tabular}{|c|c|c|c|}
\hline \multicolumn{2}{|c|}{$\begin{array}{c}\text { A Typical First-Year } \\
\text { Curriculum }\end{array}$} & \multicolumn{2}{c|}{ Constitutional Law } \\
\cline { 2 - 4 } (course names in italics) & $\begin{array}{c}\text { Privately Created } \\
\text { (Contracts) }\end{array}$ & $\begin{array}{c}\text { Publicly Created } \\
\text { (Constitutional } \\
\text { Law) }\end{array}$ \\
\hline Procedure & $\begin{array}{c}\text { Privately } \\
\text { Enforced } \\
\text { (Civ. Pro.) }\end{array}$ & $\begin{array}{c}\text { Contract } \\
\text { (None) }\end{array}$ & $\begin{array}{c}\text { Tort } \\
\text { (Torts) }\end{array}$ \\
\cline { 2 - 4 } & $\begin{array}{c}\text { Publicly } \\
\text { Enforced } \\
\text { (None) }\end{array}$ & $\begin{array}{c}\text { Parens Patriae } \\
\text { (None) }\end{array}$ & $\begin{array}{c}\text { Criminal Law } \\
\text { (Criminal Law) }\end{array}$ \\
\hline
\end{tabular}

But this apparent gap is not a defect of our method. After all, the goal is to teach law, not the laws. By this I mean to highlight that the first year is about building a fairly complete set of intuitions and arguments that need simply to be translated to apprehend a seemingly new area of law. Once the ideas of structure, rights, interpretation, and other doctrine are properly appreciated in a conventional constitutional law course, a student is well prepared to think about these problems in another setting. And especially so if these ideas have been reinforced and explicitly connected in the very different, but conceptually similar, setting of Contract.

Moreover, thinking of Contract Law as that set of law that is privately determined and privately enforced automatically raises the relevant questions that a first year contracts course resolves. When should private parties be able to lay down law that binds other private parties? The answer, quite clearly, suggests that it may only be done under voluntary conditions, And so on. A lot of the first year of contracts that is special to that course is in cashing out voluntarism and exploring the Constitutional rules meant to police it.

Property. Finally, some readers may notice an apparent gaping hole in the categorization that is near and dear to my own heart as a teacher of Property Law: the absence of Property Law. It is my view that Property Law does not exist as a substantive body of law. Rather, Property is an example of a very important concept in any 
practical legal regime: polymorphism. The claim here is that law could not be administered without frequent resort to a small number of concepts, combined in various ways, and with subtly differing shades of meaning between the categories in the taxonomy. Property is perhaps the most important, but not the only, polymorphic legal object, meaning a concept that has more or less the same meaning in many different areas of law and so can be used throughout a legal code without greatly increasing the complexity, and thus cost, of the system. Consider causation, reliance, due process, and the like, as other examples of polymorphic legal objects. Behind each such object are atomic arguments, like the ones discussed here. Importantly, many of these objects are treated uniformly within the categories in the model presented here. Many of their differences among categories can be explained by the institutional differences between public and private control.

While the model is primarily integrative of ideas that have existed in other fields, it is this integration that permits us to see so much, using so little. Though I have left a great deal undone, I hope that the rehabilitation of "the" public/private distinction as a fundamental set of public/private distinctions continues to reveal the inherent simplicity of our legal system. 